NOAA

National Marine

Fisheries Service
Fishery Bulletin

2 established 1881 ๙
Spencer F. Baird

First U.S. Commissione of Fisheries and founder of Fishery Bulletin
Abstract-The red deepsea crab (Chaceon quinquedens) supports a small fishery of $<2000$ metric tons annually along the U.S. East Coast, but little is known about the life history of this crab. We sampled red deepsea crab from 4 sites and 3 depth strata (250-450 m, 450-700 $\mathrm{m}$, and 700-850 $\mathrm{m}$ ) in the Mid-Atlantic Bight in January 2011 and 2012 and in July 2013. Crab size decreased with depth, whereas shell age indices increased with depth. Crab occurred at temperatures from $4.6^{\circ} \mathrm{C}$ to $10.6^{\circ} \mathrm{C}$ (mean: $6.37^{\circ} \mathrm{C}$ ) and there was little difference between sexes. Size at $50 \%$ maturity $\left(\mathrm{SM}_{50}\right)$ could not be determined with chela or abdomen allometry, but $\mathrm{SM}_{50}$ was estimated at $61.6 \mathrm{~mm}$ in carapace length for females on the basis of gonopore condition. Sex ratios (M:F) involving female crab above the $\mathrm{SM}_{50}$ were $<0.5$, indicating that large males are depleted in comparison with female abundance. The proportion of ovigerous females was $33 \%$ in January 2012 and $<6 \%$ in July 2013, proportions that support the hypothesis of a biennial (or longer) reproductive cycle. Red deepsea crab probably recruit to deep water ( $>1000 \mathrm{~m}$ ), move upslope during adolescence, and become mature in the shallowest strata, before undergoing an ontogenetic migration back to intermediate depths.

Manuscript submitted 29 May 2015. Manuscript accepted 2 May 2016. Fish. Bull. 114:343-359 (2016). Online publication date: 2 June 2016. doi: 10.7755/FB.114.3.7

The views and opinions expressed or implied in this article are those of the author (or authors) and do not necessarily reflect the position of the National Marine Fisheries Service, NOAA.

\title{
Depth and temperature distribution, morphometrics, and sex ratios of red deepsea crab (Chaceon quinquedens) at 4 sampling sites in the Mid-Atlantic Bight
}

\author{
Bradley G. Stevens (contact author)' \\ Vincent Guida² \\ Email address for contact author: bgstevens@umes.edu \\ 1 Department of Natural Sciences \\ University of Maryland Eastern Shore \\ Carver Hall \\ Princess Anne, Maryland 21853 \\ 2 Northeast Fisheries Science Center \\ National Marine Fisheries Service, NOAA \\ James J. Howard Marine Sciences Laboratory \\ 74 Magruder Road, Sandy Hook \\ Highlands, New Jersey 07732
}

The red deepsea crab (Chaceon quinquedens) ranges from the Gulf of Maine to the Gulf of Mexico, at depths from 200 to $1800 \mathrm{~m}$, and temperatures of $5-8^{\circ} \mathrm{C}$ (Haefner and Musick, 1974; Wigley et al., 1975; Serchuk $^{1}$; Steimle et al., 2001; Wahle et al., 2008; $\mathrm{NEFSC}^{2}$ ). Stocks along the Atlantic coast are considered a single population and distinct from the stock in the Gulf of Mexico. Red deepsea crab support a small but valuable fishery in federally managed waters along the continental slope of southern New England and the Mid-Atlantic, a fishery that has

${ }^{1}$ Serchuk, F. M. 1977. Assessment of red crab (Geryon quinquedens) populations in the northwest Atlantic. Natl. Mar. Fish. Serv., Northeast Fish. Sci. Cent. Lab. Ref. 77-23, 15 p. [Available at website.]

2 NEFSC (Northeast Fisheries Science Center). 2009. The Northeast Data Poor Stocks Working Group report, December 8-12, 2008 meeting. Part A. Skate species complex, deep sea red crab, Atlantic wolffish, scup, and black sea bass. NOAA, Natl. Mar. Fish. Serv., Northeast Fish. Sci. Cent. Ref. Doc. 0902, 496 p. [Available at website.] been managed since 2002 by the New England Fishery Management Council (Wigley et al., 1975; Wahle et al., 2008). In recent years, 4 vessels have fished for red deepsea crab and have averaged annual landings of 1360 metric tons ( $\mathrm{t}$ ) over the time period 2002-2013, but landings have declined from 1600 to $930 \mathrm{t}$ during that period $\left(\right.$ Chute $\left.^{3}\right)$. Red deepsea crab are a data-poor fishery stock. Very little is known about their biology, abundance, growth, age, or reproduction, and, as a result, management consists primarily of controls on total allowable catch, currently set at 2688 t. Because of inadequate information on biomass, the New England Fishery Management Council Scientific and Statistical Committee has not set a fishing-induced mortality rate or determined whether the stock is in a status of overfished or overfishing (Chute et al. ${ }^{4}$ ).

\footnotetext{
${ }^{3}$ Chute, A. 2014. Personal commun. Northeast Fish. Sci. Cent., Natl. Mar. Fish. Serv., NOAA, Woods Hole, MA 02543.

${ }^{4}$ Chute, A., L. Jacobson, P. Rago, and A.
} 
Because of their extended depth range, few red deepsea crab are captured during semiannual assessment surveys conducted by the National Marine Fisheries Service. Red deepsea crab have been studied during several previous surveys. McRae (1961) found significant concentrations of crab southeast of Ocean City, Maryland, but concluded that they were too sparse to support a commercial fishery. In two surveys, abundance of populations of red deepsea crab was estimated by using towed camera systems. The first survey (Wigley et al., 1975) was conducted in 1974 before the onset of commercial fishing. The second, conducted during 2003-2005 (Wahle et al., 2008), showed a 250\% increase in overall biomass (mostly due to juveniles), after a decade of targeted harvesting of males, but a $42 \%$ decline in the biomass of large males at depths of 350-500 m where fishing occurs, as well as a decline in body condition indices (carapace length [CL]: weight ratios) (Weinberg and Keith, 2003). In addition, the size of landed crabs has declined from $114 \mathrm{~mm}$ in carapace width $(\mathrm{CW})$ in 1974 to $<90 \mathrm{~mm} \mathrm{CW}$ by 2008 (Chute et al. ${ }^{4}$ ).

There is scant information on biological parameters of red deepsea crab, such as size at maturity, fecundity, or timing of reproduction. Fecundity increases with body size (Hines, 1988). Size at maturity for female red deepsea crab has been estimated by Haefner (1977, 1978) to be between 65-75 mm CL, but a large portion of his samples were barren, indicative of biennial spawning. Size at $50 \%$ maturity has been estimated with ratios of chela width (ChW) to $\mathrm{CW}$ for the congener $C$. affinis from the Canary Islands (males: $129 \mathrm{~mm}$ CW; females: $99 \mathrm{~mm} \mathrm{CW}$ ) (Fernández-Vergaz et al., 2000), by gonad condition for C. affinis in the northeast Atlantic (males: $94 \mathrm{~mm}$ CW; females: 109 $\mathrm{mm} \mathrm{CW}$ ) (Robinson, 2008), and for male C. maritae in South Africa ( $93 \mathrm{~mm} \mathrm{CW}$ ) by using growth increment analysis (Melville-Smith, 1989). Spawning of $C$. affinis in the Canary Islands occurs from October to May, but ovigerous females were found only in March and April (López Abellán et al., 2002) and from October to March in the Azores (Pinho et al., 2001). In the Gulf of Mexico, male golden deepsea crab (C. fenneri) produce sperm in late winter and mate with females during March-April, but females do not extrude eggs until the following fall (Hinsch, 1988a, 1988b). Life history characteristics of other geryonid crab species were reviewed and compared by Hastie (Hastie, 1995).

Maturity of female crabs can be inferred from the presence of eggs, gonopore condition, or ovary development, but maturity of male crabs is difficult to determine. Male crabs may carry spermatophores, indicative of physiological maturity, at sizes well below that at

MacCall. 2009. Deep sea red crab. In Northeast Data Poor Stocks Working Group report, December 8-12, 2008 meeting. Part A. Skate species complex, deep sea red crab, Atlantic wolffish, scup, and black sea bass. NOAA, Natl. Mar. Fish. Serv., Northeast Fish. Sci. Cent. Ref. Doc. 09-02, p. 181-214. [Available at website.] which they can mate. Many genera (e.g., Chionoecetes, Lithodes, Cancer) exhibit allometric growth of the chelae at the pubertal molt, after which they are classified as morphometrically mature and are distinguishable by an increase in the slope and intercept of the ratio of chela height (ChH) to $\mathrm{CW}$ (ChH:CW) (Somerton, 1980; Somerton and MacIntosh, 1983; Comeau and Conan, 1992; Stevens, et al., 1993; Corgos and Freire, 2006).

Lack of biological, survey, and fishery information for the red deepsea crab causes major uncertainties about the status of its stock and possible management approaches. Up to $85 \%$ of the catch of this species consists of females and undersize crab that are discarded and that result in a possible mortality of about $5 \%$ (Tallack, 2007). At present, it is not possible to calculate biological reference points (e.g., biomass or fishing-induced mortality at maximum sustainable yield [B $\mathrm{B}_{\mathrm{MSY}}, \mathrm{F}_{\mathrm{MSY}}$, respectively]) because of a lack of information on growth, longevity, and mortality (NEFSC ${ }^{5}$ ). For the same reasons, it is not possible to predict future stock status, biomass, or response to changes in climate or fishing mortality. Although landings of red deepsea crab have stabilized at intermediate levels in recent years, the landed size has declined from $114 \mathrm{~mm} \mathrm{CW}$ in 1974 to $105 \mathrm{~mm} \mathrm{CW}$ in 2005, and there is concern about sperm limitation because of reductions in biomass of large males.

At a minimum, effective management requires information on growth, mortality, and size at maturity. In particular, it is necessary to know the frequency of molt and reproduction in females, the presence or absence of terminal molt and multiple fertilizations, and the status of sperm storage and fecundity. The NOAA Red Crab Working Group has made a variety of highpriority research recommendations for understanding the life history of red deepsea crab, including a better understanding of the reproductive cycle, maturity schedule, and fecundity of female red deepsea crab; of the potential reproductive consequences of removing large males from the population; and of the growth rate and molt cycle of red deepsea crab (Miller et al. ${ }^{6}$ ).

We began studies of the red deepsea crab in 2011 to provide data on reproduction and life history for this species. Data were collected aboard NOAA research vessels during 3 cruises jointly sponsored by the NOAA Northeast Fishery Science Center and the Living Marine Resources Cooperative Science Center at the University of Maryland Eastern Shore. The objectives for these cruises were to sample the continental shelf fauna during winter (in 2011 and 2012) and

\footnotetext{
${ }^{5}$ NEFSC (Northeast Fisheries Science Center). 2006. 43rd Northeast Regional Stock Assessment Workshop (43 ${ }^{\text {rd }}$ SAW): $43^{\text {rd }}$ SAW assessment summary report. NOAA, Natl. Mar. Fish. Serv., Northeast Fish. Sci. Cent. Ref. Doc.. 06-14, 54 p. [Available at website.]

6 Miller, T., R. Muller, B. O'Boyle, and A. Rosenberg. 2009. Report by the Peer Review Panel for the Northeast Data Poor Stocks Working Group, 38 p. NOAA, Natl. Mar. Fish. Serv., Northeast Fish.s Sci. Cent., Woods Hole, MA. [Available at website.]
} 


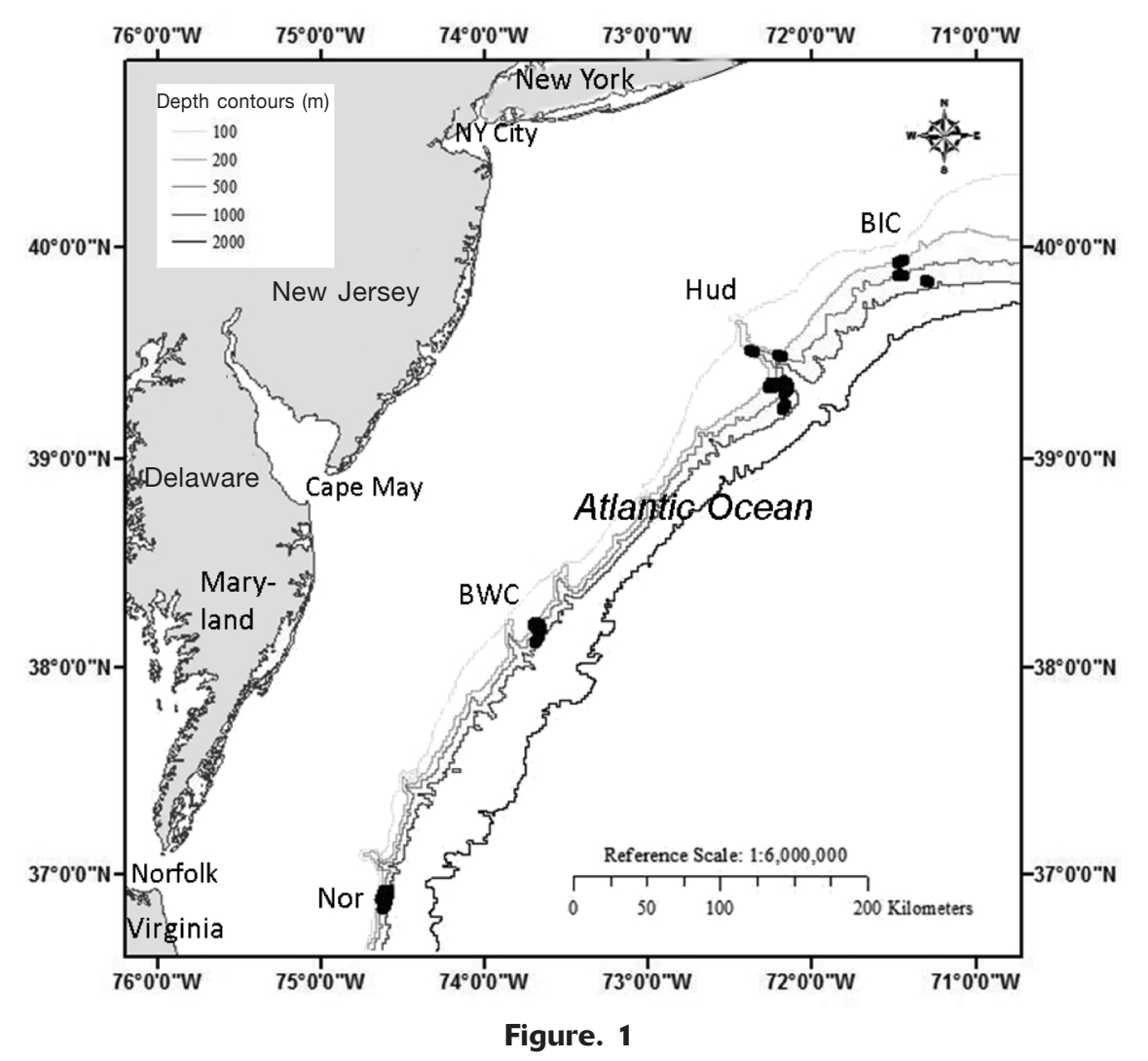

Locations of sampling sites for red deepsea crab (Chaceon quinquedens) during cruises aboard the NOAA Ship Delaware II in the MidAtlantic Bight in 2011 and 2012 and aboard the NOAA Ship Gordon Gunter in 2013. The sites were Block Island Canyon (BIC), Hudson Canyon (Hud), Baltimore and Washington Canyons (BWC), and Norfolk Canyon (Nor).

to collect samples of red deepsea crab. Specific goals for research of red deepsea crab were to determine 1) the distribution of crab by sex, size, shell condition, depth, and temperature, 2) to obtain morphometric data for determination of sexual maturity, and 3) to collect specimens for studies of reproductive biology. This article presents information on distribution and morphometry of red deepsea crab collected during the 3 NOAA cruises.

\section{Materials and methods}

\section{Sampling locations}

Two research cruises were conducted aboard the NOAA Ship Delaware II (10-21 January 2011 and 21-30 January 2012) and one cruise was completed aboard the NOAA Ship Gordon Gunter (5-8 July 2013). Red deepsea crab were sampled in 4 general areas within the Mid-Atlantic Bight (defined as coastal waters along the U.S. Atlantic coast from Cape Cod to Cape Hatteras), and stations were selected to cover a range of latitudes and depths: near Block Island Canyon (BIC), at the mouth of Hudson Canyon (Hud), on the continental slope between Baltimore and Washington Canyons (BWC), and on the slope near Norfolk Canyon (Nor; Fig. 1). Actual locations within each site where trawl nets were hauled were chosen for their relatively flat contours within specified depth ranges (see below) after reconnaissance with multibeam sonar. Goals of the cruise in 2011 were primarily focused on sampling fish; red deepsea crab were caught incidentally in the deeper $(>300 \mathrm{~m})$ tows, and sampling of crab was mostly opportunistic. In 2012 and 2013, stations were specifically defined to capture red deepsea crab, and tows were made in 3 depth strata defined as shallow $(250-450 \mathrm{~m})$, middle slope (450-700 m), and deep (700-850 m) (Table 1). One attempt to tow a trawl net at a depth of $1000 \mathrm{~m}$ failed when the net was snagged and both trawl warps were broken, resulting in loss of a trawl net. Because of inclement weather and technical delays, site BIC was sampled only in 2012, and site BWC was not sampled in 2011.

Water temperature and depth profiles were recorded with a conductivity, temperature, and depth profiler before each trawl tow at each site and depth stratum. In 2011, a Yankee 36 otter trawl with an 18.3-m headrope, 


\section{Table 1}

Data collected from trawl tows and expanded catch data from surveys of red deepsea crab (Chaecon quinquedens) conducted in the mid-Atlantic Bight during 3 cruises (2011-2013): depth stratum of trawl (Strat; 1=shallow [250-450 m], 2=middle slope [450-700 m], and 3=deep [700-850 m]); bottom temperature (Btemp, ${ }^{\circ} \mathrm{C}$ ); swept area (Area, $\mathrm{m}^{2}$ ); number of male $\mathrm{crab}$ caught (Males), number of female crab caught (Females); total number of crab caught (Total); density of male crab (Mdens, individuals/ha); density of female crab (Fdens, individuals/ha), total density of crab (Tdens, individuals/ha); expansion factor for subsampled tows (ExpFac); mean weight of male crab (Mwt, kg); and mean weight of female crab (Fwt, kg). Stations were located at 4 sites: Block Island Canyon (BIC), Hudson Canyon (Hud), Baltimore and Washington Canyons (BWC), and Norfolk Canyon (Nor).

\begin{tabular}{|c|c|c|c|c|c|c|c|c|c|c|c|c|c|c|c|}
\hline Station & Year & Date & Strat & $\begin{array}{l}\text { Depth } \\
\text { (m) }\end{array}$ & Btemp & Area & Males & Females & Total & Mdens & Fdens & Tdens & ExpFac & Mwt & Fwt \\
\hline Hud-1 & 2011 & $1 / 15 / 2011$ & 1 & 403.7 & 7.8 & 30,512 & 170 & 307 & 477 & 55.7 & 100.7 & 156.3 & 3.613 & 0.236 & 0.265 \\
\hline Hud-2 & 2011 & $1 / 15 / 2011$ & 2 & 499.4 & 6.4 & 33,057 & 480 & 655 & 1134 & 145.1 & 198.0 & 343.1 & 5.643 & 0.357 & 0.206 \\
\hline Hud-2 & 2011 & $1 / 15 / 2011$ & 2 & 558.5 & 7.3 & 31,866 & 1017 & 1645 & 2662 & 319.2 & 516.1 & 835.3 & 10.820 & 0.213 & 0.156 \\
\hline Hud-3 & 2011 & $1 / 14 / 2011$ & 2 & 631.7 & 5.5 & 31,413 & 725 & 1755 & 2480 & 230.7 & 558.8 & 789.5 & 10.206 & 0.289 & 0.130 \\
\hline Nor-1 & 2011 & $1 / 18 / 2011$ & 1 & 363.4 & 9.0 & 29,312 & 20 & 177 & 197 & 6.8 & 60.2 & 67.0 & 2.487 & 0.360 & 0.350 \\
\hline Nor-3 & 2011 & $1 / 17 / 2011$ & 2 & 580.8 & 5.1 & 26,645 & 388 & 509 & 897 & 145.7 & 190.9 & 336.6 & 6.693 & 0.263 & 0.284 \\
\hline BIC-1 & 2012 & $1 / 19 / 2012$ & 1 & 246.9 & 10.2 & 47,921 & 0 & 0 & 0 & 0.0 & 0.0 & 0.0 & 0 & & \\
\hline BIC-2 & 2012 & 1/19/2012 & 2 & 483.6 & 6.1 & 41,463 & 103 & 211 & 315 & 25.0 & 51.0 & 75.9 & 4.312 & & \\
\hline BIC-3 & 2012 & $1 / 19 / 2012$ & 3 & 731.5 & 4.6 & 30,482 & 214 & 62 & 276 & 70.1 & 20.3 & 90.4 & 3.444 & & \\
\hline Hud-1 & 2012 & 1/21/2012 & 1 & 294.0 & 11.5 & 42,011 & 0 & 0 & 0 & 0.0 & 0.0 & 0.0 & 0 & & \\
\hline Hud-2 & 2012 & $1 / 26 / 2012$ & 1 & 298.3 & 8.8 & 32,071 & 277 & 92 & 369 & 86.3 & 28.8 & 115.1 & 5.127 & & \\
\hline Hud-3 & 2012 & $1 / 26 / 2012$ & 2 & 644.2 & 6.9 & 34,345 & 125 & 200 & 326 & 36.5 & 58.3 & 94.8 & 2.022 & 0.278 & 0.20 \\
\hline BWC-1 & 2012 & $1 / 25 / 2012$ & 1 & 134.8 & 14.2 & 30,847 & 0 & 5 & 5 & 0.0 & 1.6 & 1.6 & 1 & & \\
\hline BWC-2 & 2012 & $1 / 25 / 2012$ & 2 & 571.4 & 5.6 & 25,973 & 520 & 2092 & 2612 & 200.2 & 805.3 & 1005.5 & 11.556 & 0.386 & 0.190 \\
\hline BWC-3 & 2012 & $1 / 25 / 2012$ & 3 & 760.5 & 5.1 & 27,007 & 100 & 51 & 151 & 37.0 & 18.9 & 55.9 & 1 & & \\
\hline Nor-1 & 2012 & $1 / 23 / 2012$ & 1 & 321.4 & 9.2 & 37,555 & 0 & 0 & 0 & 0.0 & 0.0 & 0.0 & 0 & & \\
\hline Nor-2 & 2012 & $1 / 23 / 2012$ & 2 & 521.9 & 6.8 & 42,703 & 377 & 882 & 1259 & 88.3 & 206.5 & 294.7 & 6.389 & & \\
\hline Nor-3 & 2012 & $1 / 22 / 2012$ & 3 & 773.7 & 4.8 & 25,800 & 90 & 64 & 154 & 34.8 & 24.8 & 59.6 & 1.830 & & \\
\hline Hud-1 & 2013 & 7/7/2013 & 1 & 263.6 & 8.1 & 34,124 & 0 & 0 & 0 & 0.0 & 0.0 & 0.0 & 0 & & \\
\hline Hud-2 & 2013 & 7/7/2013 & 2 & 569.2 & 5.7 & 42,385 & 0 & 0 & 0 & 0.0 & 0.0 & 0.0 & 0 & & \\
\hline Hud-3 & 2013 & 7/7/2013 & 3 & 792.5 & 4.8 & 32,560 & 113 & 26 & 139 & 34.7 & 8.0 & 42.7 & 1 & 0.27 & 0.326 \\
\hline BWC-1 & 2013 & 7/8/2013 & 1 & 288.7 & 11.2 & 34,070 & 1 & 10 & 11 & 0.3 & 2.9 & 3.2 & 1 & 0.306 & 0.221 \\
\hline BWC-2 & 2013 & 7/8/2013 & 2 & 500.8 & 6.5 & 33,171 & 387 & 1391 & 1778 & 116.7 & 419.4 & 536.1 & 5.610 & 0.306 & 0.221 \\
\hline Nor-1 & 2013 & 7/5/2013 & 1 & 236.5 & 12.2 & 37,488 & 0 & 0 & 0 & 0.0 & 0.0 & 0.0 & 0 & & \\
\hline Nor-2 & 2013 & $7 / 5 / 2013$ & 1 & 414.4 & 8.1 & 31,094 & 151 & 416 & 567 & 40.4 & 110.8 & 151.2 & 3.883 & 0.401 & 0.332 \\
\hline Nor-3 & 2013 & $7 / 5 / 2013$ & 3 & $750.0^{a}$ & 7.1 & 33,694 & 336 & 78 & 414 & 99.8 & 23.1 & 122.9 & 2.101 & 0.211 & 0.185 \\
\hline
\end{tabular}

${ }^{a}$ Conductivity, temperature, and depth sensor failed; depth estimated from chart.

a codend that had a 1-cm mesh liner, and deepwater headrope floats ("rock hoppers") was deployed from the stern trawl A-frame by using both trawl winches and 2.5-cm trawl wires. In 2012 and 2013, a similarly size 4-seam otter trawl net (with 6.0-cm body mesh and 2.5cm codend liner) was used. In all years, a 30-min tow was made at $\sim 1.5 \mathrm{~m} / \mathrm{s}$ (3 kt) along a specified depth contour at each site and stratum. Distance towed was determined from GPS coordinates, and area towed was estimated as the distance multiplied by average net width $(13.0 \mathrm{~m})$. Tows were made during all hours of day or night. Time constraints prevented measuring all crab in tows with larger catches (catch for 6 of the tows exceeded 1000 crab); as a result, a goal of 150-200 crab per catch was set. All catches that consisted of up to 3 baskets or a total of $60 \mathrm{~kg}$ of red deepsea crab (approximately 150 crabs) were sampled completely, whereas, for larger catches, a subsample of 2-3 baskets that composed from $10 \%$ to $50 \%$ of the catch was taken. The subsample was sorted by sex, after which males and females were weighed separately to determine the proportion of their biomass in the whole catch. A sampling factor for each tow was recorded along with each crab for later data expansion.

For each crab in a subsampled tow, the sex and shell condition were recorded. Shell condition includes coloration and abrasions of the carapace, sternum, and dactyls, and therefore provides a crude but integrated index of time since molt. Shells were classified into 4 standard categories, defined by the National Marine Fisheries Service for brachyuran crabs (see Jadamec et al., 1999), that represented relative time since molting, determined by radiometric aging (Nevissi et al., 1996). We have adapted the following cat- 
egories for red deepsea crab: 1) new-shell crab were relatively soft, clean, and brightly colored, had sharp dactyls, and indicated that the crab had molted (probably) within the last 1-2 months; 2) hard-shell crab had harder shells with some discoloration and scratches but were still glossy and may have molted within the last 6-12 months; 3) old-shell crab had lost their glossy, reflective sheen, had numerous dark patches, scratches, and dull dactyls, and probably had not molted for 2 or more years; 4) very-old-shell crab were much darker and discolored, indicating these crab had not molted for 4-6 years.

Electronic calipers were used to measure different dimensions of the crab. We used CL instead of CW as our standard dimension of size, measured from the rear margin of the right eyesocket to the rear midline of the carapace. Carapace length is a more accurate measurement because spines are usually included in $\mathrm{CW}$, and spines can wear down over time. In addition, we redefined the width measurement between spine tips as spine width (SW), as opposed to CW, which is often measured across the carapace in front of the spines. For comparative purposes, we also recorded SW for $48 \%$ and $\mathrm{CW}$ for $12 \%$ of the measured crab to allow for conversions between them. Time constraints prevented taking all measurements on all crabs, but additional measurements were taken for a subset of the sampled crabs that were systematically selected to fill out size categories for reproductive studies. Additional measurements included chela propodus length (ChL), $\mathrm{ChH}$ (males only), abdomen width (AW) at the widest point (females only), and presence and condition of eggs (females).

Haefner (1977) reported that abrasion and discoloration (blackening) around the gonopores (which he termed "vulvae") of female red deepsea crab were indications of previous mating, and he demonstrated that $87 \%$ of 67 female red deepsea crab with open, discolored gonopores contained sperm, whereas none of the 38 crabs with immature (closed) gonopores contained sperm. Therefore, in 2012 and 2013, in our surveys maturity of females was estimated on the basis of gonopore condition; females with closed and unabraded gonopores were classified as immature, whereas those with open or discolored gonopores (or external eggs) were considered mature.

\section{Data analysis}

For subsampled tows, the average weight of crab was calculated separately for males and females, and the proportion of each sex by weight was determined. Total catch for each sex $\left(C_{\mathrm{sex}}\right)$ was calculated by multiplying the total catch weight $\left(W_{\mathrm{t}}\right)$ by the weight proportion $\left(P_{\text {sex }}\right)$ and dividing the result by mean weight $\left(M W_{\text {sex }}\right)$ of each sex in the subsample:

$$
C_{\text {sex }}=W_{\mathrm{t}} \cdot P_{\mathrm{sex}} \cdot M W_{\mathrm{sex}}^{-1} .
$$

Density of crab was calculated as the catch (total number) of each sex divided by the area towed and expressed as the mean number of crab-per hectare, for comparison with results reported by Wahle et al. (2008).

Because replicate tows were not made at each station, density of each sex was compared separately between years, sites, and depth strata by using single-factor analysis of variance (ANOVA), and $P$-values $<0.05$ were considered significant. If factor effects were significant, pairwise comparisons were made with the Bonferroni correction. Likewise, differences in mean size (CL) were compared between sexes, sites, and depth strata with a weighted ANOVA, where the sampling factors were used as weights to account for unequal subsampling. Weighting had little impact on post-hoc pairwise comparisons; therefore, post-hoc comparisons were unweighted. Proportions of male and female crab within $0.5^{\circ} \mathrm{C}$ categories were also compared by using ANOVA and a Kruskal-Wallis test.

Sex ratios were calculated after summing the catch of crab in bins of $5 \mathrm{~mm} \mathrm{CL}$. Comparisons were made between sites (with depths as replicates) because sites were geographically separated. Red deepsea crab may make seasonal vertical migrations for reproduction, and crab at different depths would comingle; therefore, they were considered to represent a single local mating pool. In most brachyuran species, males are larger than females, and assortative mating is common: females pair with males up to $40 \%$ larger, as reported for snow crab (Chionoecetes opilio; Sainte-Marie et al., 1999) and southern Tanner crab (C. bairdi; Stevens et al., 1993). Male red deepsea crabs in 10 mating pairs observed by Wahle et al. (2008) were 50\% larger than their female partners, and males in 3 mating pairs observed in another study were $28 \%$ larger than their female counterparts (Elner et al., 1987). Therefore, in our study, sex ratios were calculated between numbers of crab in offset size categories. Given that the mean size of females was about $75 \mathrm{~mm} \mathrm{CL}$, the number of females in each $5-\mathrm{mm}$ bin was compared with the number of males in bins that were 20 mm larger (e.g., number of females in the bin of 50-55 $\mathrm{mm}$ CL was compared with that of males in the bin of 70-75 mm CL).

Relationships between morphometric characters, such as CL, ChL, ChH, and AW were determined for selected crabs by using analysis of covariance, with sex as a categorical factor. Data were linear and therefore were not transformed, but the slopes of the log-transformed relationships were calculated to determine the allometry coefficient. The size at $50 \%$ maturity $\left(\mathrm{SM}_{50}\right)$ for females was calculated by using logistic regression with maturity $(0,1$; determined on the basis of gonopore condition) as the dependent variable, and CL as the independent variable. Standard error (SE) of $\mathrm{SM}_{50}$ was calculated with a bootstrap analysis with 1000 repetitions. Shell conditions and proportion of mature crab with eggs were determined and plotted. All data analysis was conducted with $R$, vers. 3.0.2 ( $R$ Core Team, 2013). Most mean values are presented with standard deviations (SDs), and a few are noted with SEs. 


\section{Table 2}

Mean temperatures $\left({ }^{\circ} \mathrm{C}\right)$, with standard deviations (SD) and results of analysis of variance between years, from surveys of red deepsea crab (Chaecon quinquedens) conducted in the Mid-Atlantic Bight in 2011, 2012, and 2013. Results are averaged across all trawl tows made at each site $\left(\mathrm{Temp}_{\mathrm{s}}\right)$, weighted by numbers of crabs caught $\left(\mathrm{Temp}_{\mathrm{c}}\right.$ ), and for females with eggs $\left(\mathrm{Temp}_{\mathrm{e}}\right)$. Also shown are results of analysis of variance between years, including $F$-value $(F)$, probability $(P)$, and degrees of freedom $(\mathrm{df})$.

Year and

results of

variance

Tows

$\mathrm{Temp}_{\mathrm{s}}$

$\mathrm{Temp}_{\mathrm{c}}$

$\mathrm{Temp}_{\mathrm{e}}$

Jan 2011
Jan 2012
Jul 2013
Total
$F$
$P$
df

6
12

\section{9 (SD 1.5)}

7.8 (SD 3.0)

6.41 (SD 0.96)

6.07 (SD 1.10)

$8.0($ SD 2.6)

26

7.8 (SD 2.5)

0.361

0.701

2,23

6.71 (SD 1.11)

6.37 (SD 1.09)

44.48

$<0.001$

2,2813

$6.05(\mathrm{SD} 0.76)$

6.27 (SD 0.62)

7.68 (SD 0.72)

6.25 (SD 0.82)

26.08

$<0.001$

2,330 years, but the greatest difference was $<0.7^{\circ} \mathrm{C}$. Temperatures at which ovigerous females occurred also differed significantly among years and temperatures were warmer in July 2013 than in January of either 2011 or 2012. Although differences between stations were minimal, crab concentrated at specific depths in each season, and, as a result, crabweighted temperatures showed greater differences because of changes in crab distribution.

During the 3 cruises combined, 5594 male and 10,627 female crab were captured for a total of 16,221 crab, of which 2815 crab (17.4\%) were measured, including 1191 males ( $21.3 \%$ of males) and 1624 females (15.3\% of females). Highest mean densities occurred in the middle slope depth stra-

\section{Results}

\section{Catch and density}

During cruises of NOAA research vessels in 2011, 2012, and 2013, 26 deepwater tows were completed for research of red deepsea crab (Table 1). One site (BIC) was sampled only in 2012, whereas others were omitted in some years (e.g., BWC in 2011), and not all depths were sampled each year because of time constraints. Mean bottom temperatures at all sampled stations did not differ significantly between years despite sampling in January of 2011 and 2012 and in July of 2013 (Table 2). Temperatures weighted by number of crab captured differed significantly among tum (450-700 m; Table 3) for both males (131 individuals/ha) and females (300 individuals/ha), but differences between sites were not significant (Table 3 ). However, mean densities of male crab were significantly greater in 2011 than in 2012 or 2013; a similar but nonsignificant decline occurred for females. This difference remained even after removal of site BIC (only sampled in 2012) and was mostly due to samples at sites Hud and Nor. Estimates of biomass density were calculated with mean weights from 13 subsampled tows and ranged from 0 to $241 \mathrm{~kg} / \mathrm{ha}$, with a mean of $49.7 \mathrm{~kg} / \mathrm{ha}$ (SD 69.6). Biomass averaged across years was lowest at site BIC $(14.7 \mathrm{~kg} / \mathrm{ha}$ [SD 13.1]) and highest at site BWC (77.4 kg/ha [SD 106.4]) (Table 4).

\section{Table 3}

Mean density (individuals/ha), with standard deviations (SDs), of red deepsea crab (Chaecon quinquedens) averaged across depth strata, years, and sites sampled in the Mid-Atlantic Bight during 2011-2013. Analysis of variance results include $F$-value $(F)$, probability $(P)$, and degrees of freedom (df). Superscript letters indicate similar groups (within columns) where $P<0.05$. Sampling occurred at 3 depth strata, shallow $(250-450 \mathrm{~m})$, middle slope $(450-700 \mathrm{~m})$, and deep (700-850 m), at 4 sites, Block Island Canyon (BIC), Hudson Canyon (Hud), Baltimore and Washington Canyons (BWC), and Norfolk Canyon (Nor).

\begin{tabular}{|c|c|c|c|c|c|c|c|c|}
\hline Stratum & Male & Female & Year & Male & Female & Site & Male & Female \\
\hline Shallow & $18^{b}(\mathrm{SD} 30.7)$ & $30^{b}(\mathrm{SD} 47.7)$ & 2011 & $151^{a}(\mathrm{SD} 114)$ & $271(\mathrm{SD} 214)$ & $\mathrm{BIC}$ & $32(\mathrm{SD} 35.6)$ & $24(\mathrm{SD} 25.6)$ \\
\hline Middle & $131^{a}(\mathrm{SD} 100)$ & $300^{a}(\mathrm{SD} 263)$ & 2012 & $48^{b}(\mathrm{SD} 57.9)$ & 101 (SD 229) & BWC & 71 (SD 86.6) & $250($ SD 358) \\
\hline \multirow[t]{2}{*}{ Deep } & $55^{b}(\mathrm{SD} 29.0)$ & $19^{b}(\mathrm{SD} 6.6)$ & 2013 & $37^{b}(\mathrm{SD} 47.6)$ & $73(\mathrm{SD} 147)$ & Hud & $81(\mathrm{SD} 98.2)$ & $125(\mathrm{SD} 193)$ \\
\hline & & & & & & Nor & $55(\mathrm{SD} 61.4)$ & $96(\mathrm{SD} 95.9)$ \\
\hline \multicolumn{9}{|c|}{ Analysis of variance } \\
\hline$F$ & 2.559 & 0.47 & & 7.263 & 2.97 & & 0.319 & 0.817 \\
\hline$P$ & 0.123 & 0.5 & & 0.013 & 0.09 & & 0.811 & 0.498 \\
\hline $\mathrm{df}$ & 2,23 & 2,23 & & 1,24 & 1,24 & & 3,22 & 3,22 \\
\hline
\end{tabular}




\section{Table 4}

Total biomass density ( $\mathrm{kg} / \mathrm{ha}$ ) of red deepsea crab (Chaecon quinquedens) at each site and depth stratum sampled in the Mid-Atlantic Bight during 2011-2013, and summaries across sites and depth strata are provided. Sampling occurred at 3 depth strata, shallow (250-450 $\mathrm{m})$, middle slope (450-700 m), and deep (700-850 m), at 4 sites, Block Island Canyon (BIC), Hudson Canyon (Hud), Baltimore and Washington Canyons (BWC), and Norfolk Canyon (Nor).

\begin{tabular}{llcrrr}
\hline & & \multicolumn{4}{c}{ Depth stratum } \\
\cline { 3 - 6 } Year & Site & Shallow & Middle & Deep & Mean \\
\hline 2011 & Hud & 39.8 & 126.8 & & 105.1 \\
2011 & Nor & 0 & 92.5 & & 92.5 \\
2012 & BIC & 0 & 18.9 & 25.2 & 14.7 \\
2012 & Hud & 16.0 & 21.6 & & 17.9 \\
2012 & BWC & 0.0 & 241.4 & 17.9 & 86.4 \\
2012 & Nor & 0.0 & 72.8 & 15.9 & 29.5 \\
2013 & Hud & 0.0 & 0.0 & 9.7 & 3.2 \\
2013 & BWC & 1.0 & 128.4 & & 64.2 \\
2013 & Nor & 32.0 & & 25.3 & 29.8 \\
Mean & & 13.6 & 95.6 & 18.8 & 47.4 \\
& & & & & \\
\hline
\end{tabular}

\section{Size of crab}

Carapace length was measured on all sampled crabs except for 133 crab from site BIC in 2012; for those crab, CL was calculated from the regression of CL on SW and used in all further analyses. The mean size of male crab captured (79.4 $\mathrm{mm}$ CL [SD 14.7], range: 31.6-126.5 mm CL) was significantly greater $(t=11.62$, $\mathrm{df}=1974, P<0.0001)$ than that of female crab $(73.7 \mathrm{~mm}$ CL [SD 10.1], range: 26.5-103.6 mm CL). Mean size of males differed between years (weighted $F$, Table 5 ) and was lower in July 2013 (73.9 mm CL [SD 17.5]) than in January 2011 (80.5 mm CL [SD 10.6]) or 2012 (83.2 mm CL [SD 13.6]). Mean size of females also differed between years (weighted $F$, Table 5 ), but pairwise comparisons among years were not significant. Lack of sampling at some sites and depths prevented making annual comparisons among all samples; therefore, further comparisons were made by combining data across years. Mean weights determined from 13 subsampled tows (for which sexes were weighed in aggregate) were $294 \mathrm{~g}$ (SD 68) for males and $227 \mathrm{~g}$ (SD 71) for females.

Length-frequency distribution of males showed a mode in the range of $80-90 \mathrm{~mm}$ CL, and a distinct drop in abundance at sizes $>90 \mathrm{~mm}$ CL (Fig. 2). Hard-shell crab predominated below $70 \mathrm{~mm}$ CL, old-shell crabs were more abundant from 75 to $100 \mathrm{~mm} \mathrm{CL}$, and most crabs $>100 \mathrm{~mm}$ CL were classified as very-old-shell. Female crab exhibited a mode at 70-75 mm CL. Hardshell females predominated below $60 \mathrm{~mm} \mathrm{CL}$, and oldshell females were more abundant in all size groups above $60 \mathrm{~mm}$ CL.

\section{Morphometrics}

Sex did not affect the relationship between CL and SW; therefore, a combined regression equation was derived for both sexes (Tables 5 and 6; Fig. 3A). The inverse relationship was also determined and used to predict CL for 133 crab that were missing CL measurements. The relationship between ChL and CL differed between sexes with a significant interaction (Table 5); males had longer chelae at sizes $>50 \mathrm{~mm} \mathrm{CL}$, but females had longer chelae below $50 \mathrm{~mm}$ CL (Fig. 3B). Males had an allometry coefficient (the log-transformed slope) of 1.09 , indicating isometric growth, whereas females had an allometry coefficient of 0.862 , implying slight negative allometry. Among male crab, the relationship between $\mathrm{ChH}$ and $\mathrm{CL}$ had an allometry coefficient of 1.16, indicating slightly positive allometry (Table 6, Fig. 3C), and the relationship between $\mathrm{ChH}$ and ChL had an allometry coefficient of 1.06 (Fig. 3D). Neither the relationship between ChL and CL nor the relationship between $\mathrm{ChH}$ and $\mathrm{ChL}$ revealed any apparent inflections in the growth pattern that could be used to determine maturity. The relationship between female AW and CL was significant but did not differ with maturity status (Table 5). Nonetheless, there was a significant interaction effect; therefore, combined and separate equations for immature and mature females are presented in Table 6.

\section{Distribution by depth, temperature, crab size, and shell condition}

Females were more abundant than males at depths from 400 to $650 \mathrm{~m}$, but males predominated at greater depths (Fig. 4). Weighted ANOVA showed that size varied with both depth and sex, and a significant interaction occurred (Table 5). Mean CL of male crab decreased with depth: $83.1 \mathrm{~mm}$ CL (SD 13.7), $79.7 \mathrm{~mm}$ CL (SD 11.6), and $78.2 \mathrm{~mm} \mathrm{CL} \mathrm{(SD} \mathrm{17.9)} \mathrm{in} \mathrm{the} \mathrm{shal-}$ low, middle slope, and deep strata, respectively (Fig. 5A). Mean CL for males differed significantly between the shallow and deep strata (pairwise $t$-test, $P<0.05$ with Bonferroni correction), but the values for neither strata differed from the middle slope stratum. Mean CL of females also decreased with depth to a greater degree than it did for males (Table 5, Fig. 5B): $80.6 \mathrm{~mm}$ CL (SD 10.1), $73.8 \mathrm{~mm} \mathrm{CL} \mathrm{(SD} \mathrm{9.1),} \mathrm{and} 67.0 \mathrm{~mm} \mathrm{CL}$ (SD 12.8) in the shallow, middle slope, and deep strata, respectively, and all differed significantly $(P<0.05)$. Mean CL of male crab did not differ between sites (Table 5, Fig. 6C), whereas mean CL of female crab was significantly greater at site Nor than at all other sites $(P<0.05$; Fig. 6D).

Mean shell condition for males was significantly less in stratum 1 (2.2) than in stratum $2(2.6)$ or stratum 3 (2.5), but the latter 2 strata did not differ significantly (Fig. 6A). Mean shell condition for females was significantly greater in stratum 2 (2.8) than in either stratum 1 or 3 (both 2.4), but strata 1 and 3 did not differ significantly (Fig. 6B). New-shell male crab were most 
Table 5

Analysis of variance results for comparisons among carapace length (CL), year, sex, shell width (SW), chela propodus length (ChL), site, depth or stratum, shell condition, bottom temperature (Btemp), abdomen width (AW), and maturity (females only) of red deepsea crab (Chaecon quinquedens) captured from the Mid-Atlantic Bight during 2011-2013. Other abbreviations: $\mathrm{df}=$ degrees of freedom, $\mathrm{SS}=$ Sum of squares, $\mathrm{MS}=\mathrm{Mean}$ square, $F=\mathrm{F}$-value, $P=\mathrm{P}$-value.

\begin{tabular}{|c|c|c|c|c|c|c|}
\hline Response & Predictor & $\mathrm{df}$ & SS & MS & $F$ & $P$ \\
\hline CL (males) & $\begin{array}{l}\text { Year } \\
\text { Residual }\end{array}$ & $\begin{array}{r}1 \\
1189\end{array}$ & $\begin{array}{r}5233 \\
932,745\end{array}$ & $\begin{array}{r}5233 \\
784\end{array}$ & 6.67 & 0.01 \\
\hline CL (females) & $\begin{array}{l}\text { Year } \\
\text { Residual }\end{array}$ & $\begin{array}{r}1 \\
1622\end{array}$ & $\begin{array}{r}19,286 \\
923,249\end{array}$ & $\begin{array}{r}19,286 \\
569\end{array}$ & 33.88 & $<0.001$ \\
\hline SW & $\begin{array}{l}\text { CL } \\
\text { Sex } \\
\text { Residual }\end{array}$ & $\begin{array}{r}1 \\
1 \\
1313\end{array}$ & $\begin{array}{r}427,647 \\
0 \\
10,719\end{array}$ & $\begin{array}{r}427,647 \\
0\end{array}$ & $\begin{array}{r}52,382 \\
0.020\end{array}$ & $\begin{array}{r}<0.001 \\
0.887\end{array}$ \\
\hline $\mathrm{ChL}$ & $\begin{array}{l}\text { CL } \\
\text { Sex } \\
\text { CL } \times \text { sex } \\
\text { Residual }\end{array}$ & $\begin{array}{r}1 \\
1 \\
1 \\
321\end{array}$ & $\begin{array}{r}76,716 \\
3505 \\
1555 \\
1893\end{array}$ & $\begin{array}{r}76,716 \\
3505 \\
1555 \\
6\end{array}$ & $\begin{array}{r}13,008 \\
594 \\
263\end{array}$ & $\begin{array}{l}<0.001 \\
<0.001 \\
<0.001\end{array}$ \\
\hline AW (females) & $\begin{array}{l}\text { CL } \\
\text { Maturity } \\
\text { CL } \times \text { maturity } \\
\text { Residual }\end{array}$ & $\begin{array}{r}1 \\
1 \\
1 \\
179\end{array}$ & $\begin{array}{r}19,761 \\
8.1 \\
20.2 \\
666.2\end{array}$ & $\begin{array}{r}19,761 \\
8.1 \\
20.2 \\
3.7\end{array}$ & $\begin{array}{r}5310 \\
2.17 \\
5.43\end{array}$ & $\begin{array}{r}<0.001 \\
0.143 \\
0.021\end{array}$ \\
\hline CL & $\begin{array}{l}\text { Depth } \\
\text { Sex } \\
\text { Sex } \times \text { depth } \\
\text { Residual }\end{array}$ & $\begin{array}{r}1 \\
1 \\
1 \\
2811\end{array}$ & $\begin{array}{r}90,540 \\
140,428 \\
24,764 \\
1,765,210\end{array}$ & $\begin{array}{r}90,540 \\
140,428 \\
24,764 \\
628\end{array}$ & $\begin{array}{r}144 \\
224 \\
39.4\end{array}$ & $\begin{array}{l}<0.0001 \\
<0.0001 \\
<0.0001\end{array}$ \\
\hline CL (male) & $\begin{array}{l}\text { Depth } \\
\text { Residual }\end{array}$ & $\begin{array}{r}1 \\
1189\end{array}$ & $\begin{array}{r}7915 \\
930,063\end{array}$ & $\begin{array}{r}7915 \\
782\end{array}$ & 10.1 & 0.002 \\
\hline CL (female) & $\begin{array}{l}\text { Depth } \\
\text { Residual }\end{array}$ & $\begin{array}{r}2 \\
1621\end{array}$ & $\begin{array}{r}35,721 \\
906,814\end{array}$ & $\begin{array}{r}17,861 \\
559\end{array}$ & 31.9 & $<0.001$ \\
\hline CL (male) & $\begin{array}{l}\text { Site } \\
\text { Residual }\end{array}$ & $\begin{array}{r}3 \\
1187\end{array}$ & $\begin{array}{r}3644 \\
934,334\end{array}$ & $\begin{array}{r}1215 \\
787\end{array}$ & 1.54 & 0.202 \\
\hline CL (female) & $\begin{array}{l}\text { Site } \\
\text { Residual }\end{array}$ & $\begin{array}{r}3 \\
1620\end{array}$ & $\begin{array}{r}57,588 \\
884,947\end{array}$ & $\begin{array}{r}19,196 \\
546\end{array}$ & 35.14 & $<0.001$ \\
\hline Shell (male) & $\begin{array}{l}\text { Stratum } \\
\text { Residual }\end{array}$ & $\begin{array}{r}2 \\
1188\end{array}$ & $\begin{array}{r}82.2 \\
1911\end{array}$ & $\begin{array}{l}41.1 \\
1.61\end{array}$ & 25.5 & $<0.001$ \\
\hline Shell (female) & $\begin{array}{l}\text { Stratum } \\
\text { Residual }\end{array}$ & $\begin{array}{r}2 \\
1621\end{array}$ & $\begin{array}{r}103 \\
2518\end{array}$ & $\begin{array}{l}51.6 \\
1.55\end{array}$ & 33.2 & $<0.001$ \\
\hline Btemp & $\begin{array}{l}\text { Sex } \\
\text { Residual }\end{array}$ & $\begin{array}{r}1 \\
2813\end{array}$ & $\begin{array}{r}31.4 \\
14,683\end{array}$ & $\begin{array}{l}31.4 \\
5.22\end{array}$ & 6.02 & 0.014 \\
\hline Btemp (female) & $\begin{array}{l}\text { Eggs } \\
\text { Residual }\end{array}$ & $\begin{array}{r}1 \\
1406\end{array}$ & $\begin{array}{r}362 \\
6759\end{array}$ & $\begin{array}{r}362 \\
4.81\end{array}$ & 75.4 & $<0.001$ \\
\hline
\end{tabular}

abundant in the shallow stratum $(<450 \mathrm{~m})$, whereas new-shell females were most abundant in the deep stratum $(>700 \mathrm{~m})$. Hard-shell male crab predominated in the shallow and deep strata, whereas old-shell crab predominated in the middle slope stratum. Hard-shell female crab predominated in the shallow strata, whereas old-shell females predominated in the middle slope and deep strata.

Bottom temperatures at which crabs were captured ranged from $4.6^{\circ} \mathrm{C}$ to $10.6^{\circ} \mathrm{C}$, but mean temperatures differed by sex (Table 5). The mean temperatures at which crab were captured were $6.27^{\circ} \mathrm{C}$ (SD 1.18) for males $(n=1191)$ and $6.45^{\circ} \mathrm{C}$ (SD 1.01) for females $(n=1624)$. Because these data were not normally distributed, a Kruskal-Wallis analysis was conducted and also indicated significant differences $\left(\chi^{2}=20.12, P<0.0001\right)$. Ovigerous females occurred at slightly colder temperatures $\left(6.25^{\circ} \mathrm{C}\right.$ [SD 0.82$\left.]\right)$ than those temperatures at which females without eggs were found $\left(6.59^{\circ} \mathrm{C}\right.$ [SD 1.05]; Kruskal-Wallis test $\left(\chi^{2}=26.69, P<0.0001\right)$. Only 11 crabs were caught at temperatures above $9.0^{\circ} \mathrm{C}$; these crab were captured in one sample at a temperature of $11.2^{\circ} \mathrm{C}$ and 


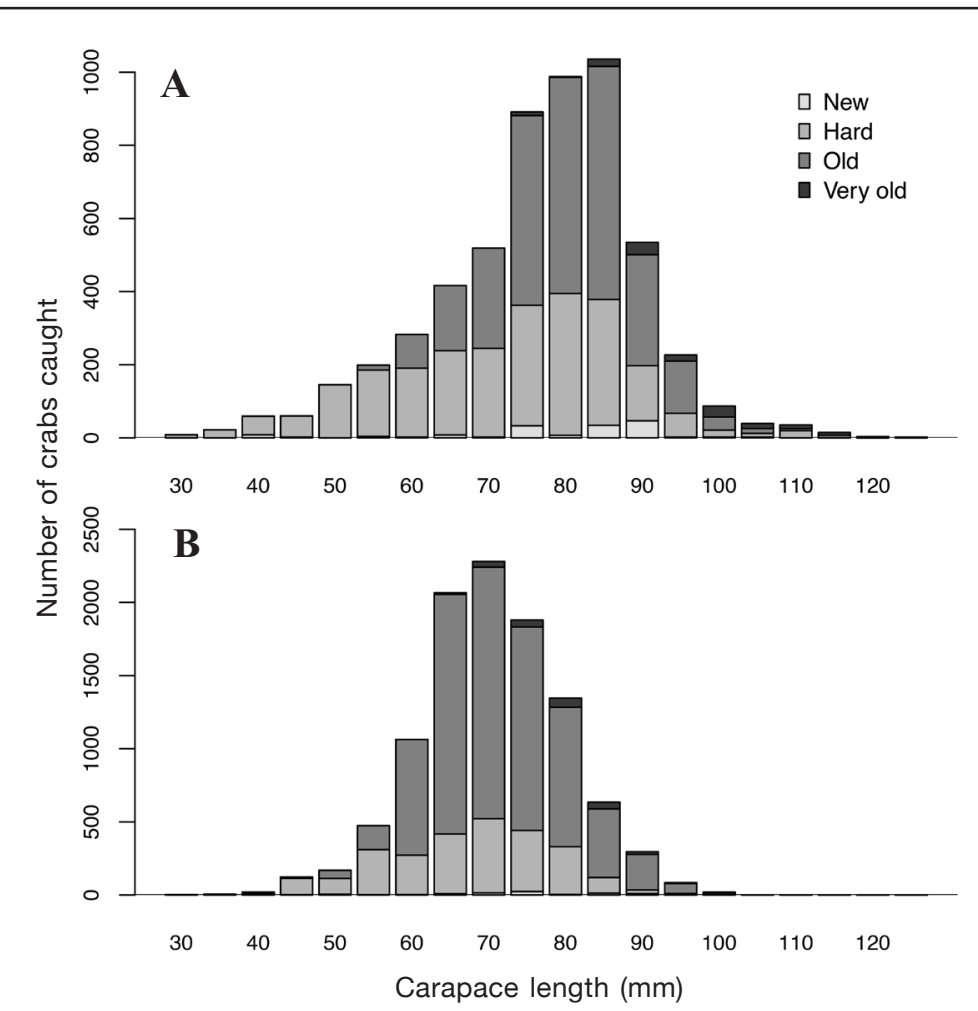

Figure 2

Length-frequency distributions and shell conditions of (A) male and (B) female red deepsea crab (Chaceon quinquedens) captured during cruises in the Mid-Atlantic Bight in 2011-2013. Note that vertical scales differ between sexes.

depth of $288 \mathrm{~m}$. There was no relationship between temperature and size (CL) of male crab $(F=0.833$, coefficient of determination $\left.\left[r^{2}\right]=-0.0001, P=0.362, \mathrm{df}=1189\right)$, but size of female crab increased with temperature $(F=31.3$, $r^{2}=0.018, P<0.001, \mathrm{df}=1622$ ).

Sex ratios (M:F) varied greatly both among sizes and between sampling sites. For pairs in the smallest size group for their sex (females: 55-60 mm CL; males: 75-80 $\mathrm{mm}$ CL) and in which females carried eggs, sex ratios ranged from 2.1 to 3.6; however, for the interval in which female sexual maturity occurs (60-65 mm CL), ratios exceeded 1.0 only at sites BIC and Nor (Fig. 7). For females between 70 and $80 \mathrm{~mm}$ CL, only site BIC had a sex ratio $>0.5$, and ratios at all other sites were $<0.4$. For females $>80 \mathrm{~mm}$ CL, there were no sites or size categories where sex ratios exceeded 0.1. At female sizes above $60 \mathrm{~mm}$ CL, crab at sites BIC and Nor generally had higher sex ratios than crab at sites Hud or BWC.

\section{Female maturity and ovigerity}

The smallest female with external eggs was $58.5 \mathrm{~mm}$ CL. Logistic regression of maturity, based on gonopore condition, showed that the $\mathrm{SM}_{50}$ was $61.6 \mathrm{~mm}$ CL (SE 0.1), equivalent to $78.2 \mathrm{~mm} \mathrm{SW} \mathrm{(Fig.} \mathrm{8).} \mathrm{In}$
January 2012, $33.3 \%$ of mature female crab were ovigerous, and the maximum proportion exceeded $50 \%$ only in the size group of 95-100 mm CL (Fig. 9). In contrast, in July 2013 , only $5.9 \%$ of mature female crab were ovigerous, and the maximum proportion was $17.9 \%$ in the size group of 80-85 $\mathrm{mm}$ CL. Analysis of egg samples taken in July 2013 indicated that $80 \%$ of eggs were at stage 6 (prehatching or hatching stage), whereas $20 \%$ of eggs were at stage 1 (early cell division).

\section{Discussion}

Our results add significantly to previous studies of red deepsea crab. Wigley et al. (1975) sampled extensively off the southern New England shelf but included only 2 stations off the Maryland coast, and all sites sampled by Wahle et al. (2008) were north of Delaware Bay (at approximately $38^{\circ} 40^{\prime} \mathrm{N}$ ). We sampled 2 sites (BWC and Nor) that were farther south and that represent locations that are targeted heavily by the current commercial fishery. In addition, we captured about 10 times more crabs than Wigley et al. (1975) and twice as many as Wahle et al. (2008), and we sampled twice as many females as Haefner (1977). Our report is the first to conduct detailed analysis of morphometrics of the red deepsea crab and the first to provide detailed information on distribution by temperature and shell condition.

\section{Catch and density}

Tows made during our cruises were not optimized for estimating abundance of red deepsea crab because the net was not outfitted with mensuration gear to measure the net width or bottom contact. As a result, area towed was estimated on the basis of the operator's (subjective) estimate of contact time, distance towed, and average net width. Furthermore, differences in vessel characteristics, operational protocols, and net efficiency make any direct comparisons with previous surveys questionable. The trawl nets we used had a belly mesh of $6 \mathrm{~cm}$ and smaller mesh codend liners than those in nets with 3.8-cm mesh used by Wigley et al (1975) and Wahle et al (2008), but all trawl nets caught a similar size range of crab and few crab $<50$ $\mathrm{mm}$ SW. Nonetheless, because there are no other estimates of density of red deepsea crab, our data can be compared with previous estimates in a relative context.

Two of our sites (Hud and BWC) overlap with the area defined as "geographic zone A" by Wigley et al. (1975) (referred to as "sectors" by Wahle et al [2008]). Therefore, we estimated biomass density of red deepsea crab separately within each depth stratum over those 2 

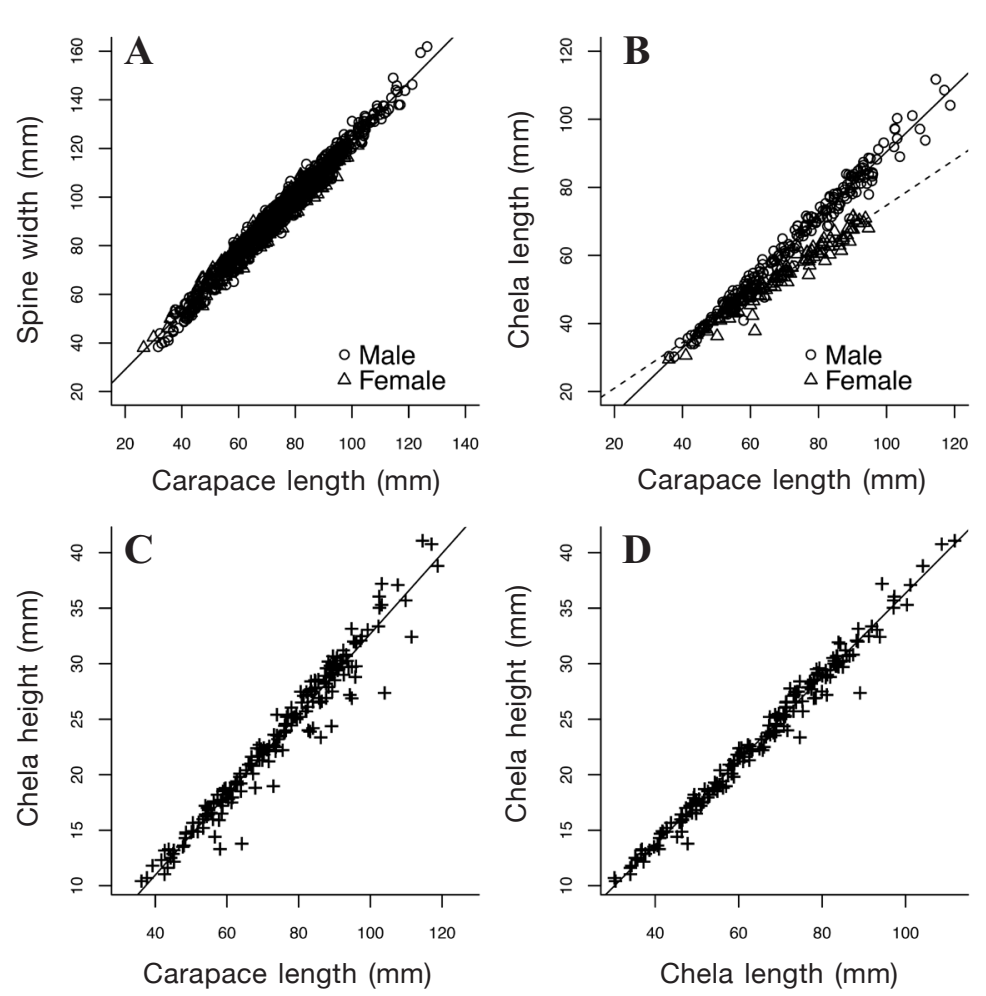

Figure 3

Morphometric relationships for a subsample of 185 male and 138 female red deepsea crab (Chaceon quinquedens) captured in the MidAtlantic Bight during 2011-2013: (A) carapace width with spines (spine width) versus carapace length, (B) chela length versus carapace length, (C) male chela height versus carapace length, and (D) male chela height versus chela propodus length. sites $(12.6,107.5$, and $13.8 \mathrm{~kg} / \mathrm{ha}$, respectively), and we multiplied those values by area estimates for similar depth strata within the same geographic sector from Wahle et al. (2008) to provide a depthstratified estimated biomass of $9143 \mathrm{t}$ for sector A. This value was lower than the approximately $30,000 \mathrm{t}$ estimated by Wahle (2008) during 2003-2005, but it is almost identical to the $9000 \mathrm{t}$ estimated by Wigley et al. (1975) 20 years earlier. We could not separate biomass by sex or size because crab were usually weighed in aggregate. During the survey by Wahle et al. (2008), the highest biomass densities occurred in sectors $\mathrm{C}$ and $\mathrm{D}$ along the edge of the southern New England shelf, whereas most of our tows were made in sectors A and B, which had the lowest biomass in both the 1974 and 2003-2005 surveys. Mean biomass density over all our stations $(42.8 \mathrm{~kg} / \mathrm{ha})$ was in the same range $(7-80 \mathrm{~kg} / \mathrm{ha}$ ) as levels observed for C. maritae off Namibia (Hastie, 1995), but it was much greater than the $1.9 \mathrm{~kg} /$ ha calculated for the golden deepsea crab off the coast of South Carolina (Wenner and Barans, 1990) that were surveyed with an occupied submersible.

\section{Size of crabs}

Selectivity of commercial crab traps ranges from $0 \%$ at $80 \mathrm{~mm} \mathrm{CW}$ to $100 \%$ at $120 \mathrm{~mm} \mathrm{CW}$ (Wahle et al., 2008),

\section{Table 6}

Morphometric relationships for male and female red deepsea crab (Chaecon quinquedens) captured from the mid-Atlantic Bight during 2011-2013. Response and predictor variables are, abdomen width (AW), chela propodus length $(\mathrm{ChL})$, carapace length $(\mathrm{CL})$, spine width (SW). Fem(i or $\mathrm{m}$ ) refers to immature or mature females. Other abbreviations: intercept (Int), coefficient of determination $\left(r^{2}\right)$, degrees of freedom ( $\mathrm{df}$ ), and allometry coefficient (AC; slope of log-transformed relationship).

\begin{tabular}{lccrcrrr}
\hline Sex & Response & Predictor & Int & Slope & $r^{2}$ & df & AC \\
\hline Both & SW & CL & 5.45 & 1.180 & 0.976 & 1313 & 0.94 \\
Both & CL & SW & -2.65 & 0.826 & 0.976 & 1313 & 1.03 \\
Male & ChL & CL & -5.78 & 0.962 & 0.977 & 184 & 1.09 \\
Fem & ChL & CL & 7.55 & 0.671 & 0.952 & 137 & 0.86 \\
Fem(i) & AW & CL & -13.0 & 0.735 & 0.967 & 105 & 1.40 \\
Fem(m) & AW & CL & -8.38 & 0.677 & 0.937 & 74 & 1.19 \\
Fem(all) & AW & CL & -12.26 & 0.725 & 0.966 & 182 & \\
Male & ChH & CL & -3.52 & 0.362 & 0.954 & 184 & 1.16 \\
Male & ChH & ChL & -1.44 & 0.378 & 0.983 & 184 & 1.06
\end{tabular}


equivalent to a range of $63.4-96.5 \mathrm{~mm} \mathrm{CL}$, and the median size of crab captured by traps was $92.5 \mathrm{~mm} \mathrm{CW}$, or $73.8 \mathrm{~mm}$ CL. Therefore, abundance of males declines abruptly above 90 $\mathrm{mm}$ CL, which approximately corresponds with the minimum size captured by the fishing industry. Width frequencies of crab captured by Wahle et al. (2008) during 2003-2005 showed a mode in the range of $65-75 \mathrm{~mm} \mathrm{CW}$ (equivalent to 51-59 $\mathrm{mm} \mathrm{CL}$ ) for males and in the range of 95-105 $\mathrm{mm} \mathrm{CW} \mathrm{(76-84} \mathrm{mm} \mathrm{CL}$ ) for females. In contrast, male red deepsea crab captured during our study were larger, with a mode in the range of $80-90 \mathrm{~mm} \mathrm{CL}$, whereas females were slightly smaller, with a mode at 70-75 mm CL.

Differences in mean size of male and female red deepsea crab $(79.4$ and $73.7 \mathrm{~mm}$ $\mathrm{CL}$, respectively, equivalent to 99.1 and 92.4

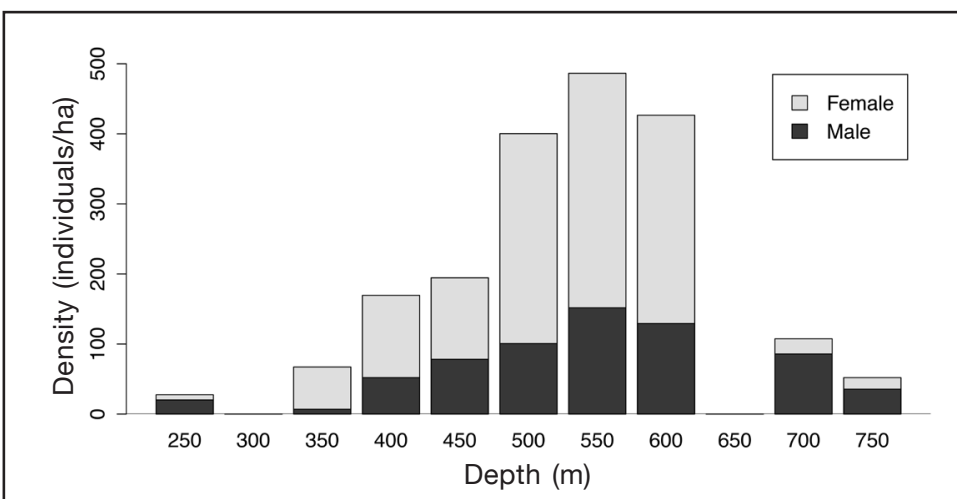

Figure 4

Depth distribution of male and female red deepsea crab (Chaceon quinquedens) captured during 2011-2013 in the Mid-Atlantic Bight, expressed as density or number of crab per hectare (ha). Minimum depths are shown for each 50-m depth bin.

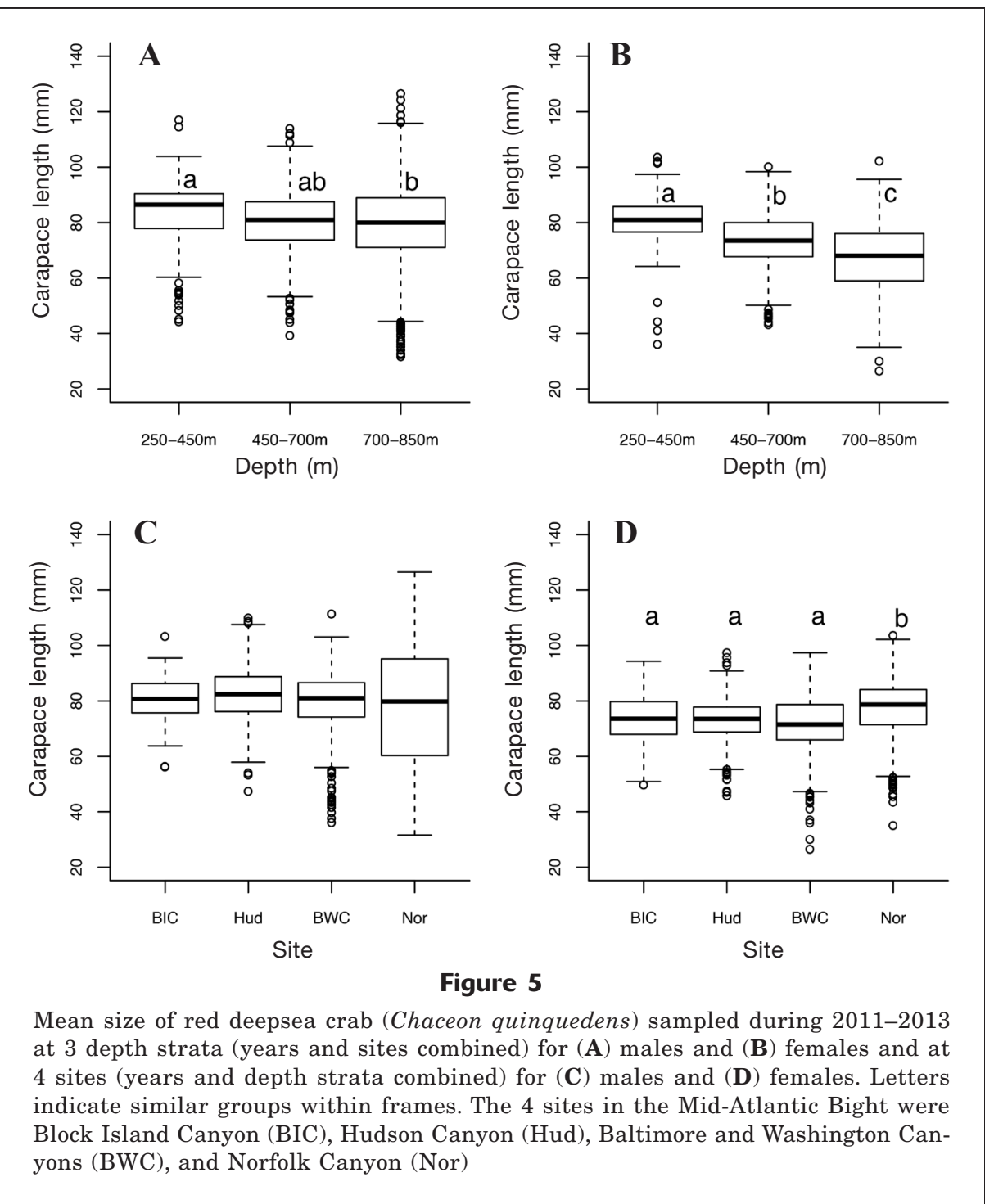




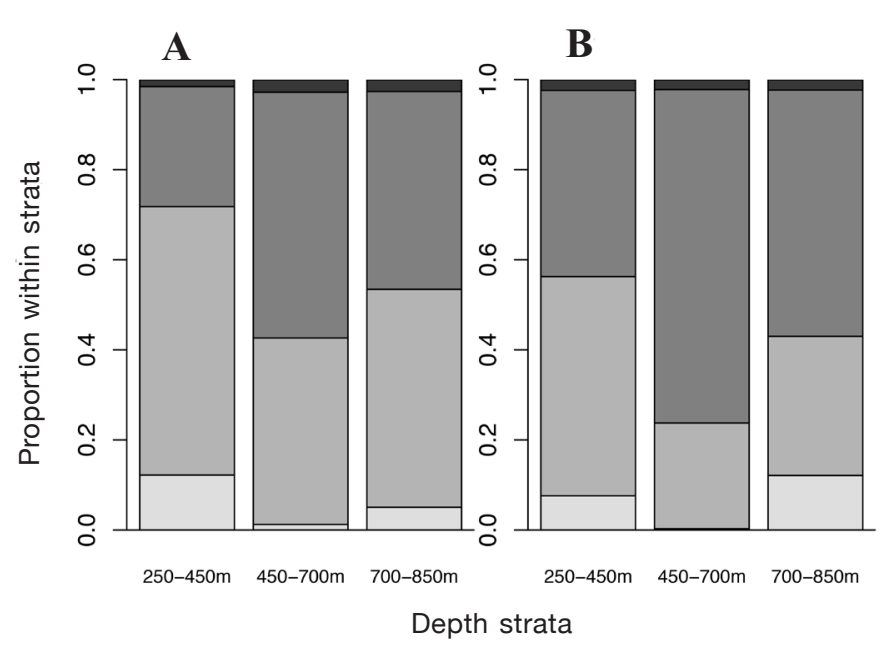

Figure 6

Proportion of (A) male and (B) female red deepsea crab (Chaceon quinquedens) in each of 4 categories of shell condition at 3 depth strata sampled in the Mid-Atlantic Bight during 20112013 (years and sites combined). Shell conditions are new (light gray), hard (medium gray), old (dark gray), and very old (black). population, but they are usually calculated over large geographic areas. However, functional maturity (i.e., the ability of male crabs to mate in competitive, natural environments) is dependent on both size (Paul, 1984) and shell condition (Stevens, et al., 1993) because harder shells are necessary to grasp females and defend them from other males. As a result, the effective sex ratio of mating-capable partners may vary greatly over small geographic areas. For this reason we calculated effective sex ratio only within sampling sites, where the samples were geographically close, and these ratios were calculated between abundance of females in 5-mm-CL bins and abundance of males that were $20 \mathrm{~mm}$ CL larger. We also ignored shell condition and depth because both could change between the time sampled and mating season, and we did not include year effects in order to preserve adequate sample sizes.

Sex ratios were generally biased toward males in the smaller size intervals, but for intervals larger than the $\mathrm{SM}_{50}$ for female red deepsea crab, all ratios were $<0.7$, and many ratios were much lower. These data indicate that male mating partners for females bemm SW) have been previously noted (McRae, 1961; Haefner, 1978; Weinberg and Keith, 2003). According to McRae (1961), mean weights for a "random sample" of crabs were $794 \mathrm{~g}$ for males, and $312 \mathrm{~g}$ for non-ovigerous females, equivalent to sizes of $116.4 \mathrm{~mm} \mathrm{CL}$ and 88.4 $\mathrm{mm} \mathrm{CL}$, respectively, or 144.2 and 110.2 $\mathrm{mm}$ SW (converted with the equation for CW from Weinberg and Keith, 2003). The source of this sample was not described, but presumably it was near our sampling area. Therefore, either mean size of red deepsea crab has declined significantly since McRae's study in 1960 , or his random sample was biased toward large crab. The mean size of male crab reported by McRae (1961) was $31 \%$ larger than the mean size of females. This difference is similar to the mean size differential of $27.9 \%$ reported by Elner et al. (1987) for 3 pairs of crab (involving 2 males and 2 females) observed mating in captivity, but it is smaller than the differential of $50 \%$ between 10 mating pairs observed by Wahle et al. (2008) during tows with video cameras. Although sample sizes for the latter 2 studies were small, they indicate that the relative size of male and female crabs observed by McRae (1961) offered adequate opportunities for mating.

Sex ratios are commonly used to determine whether fishing has affected a crab

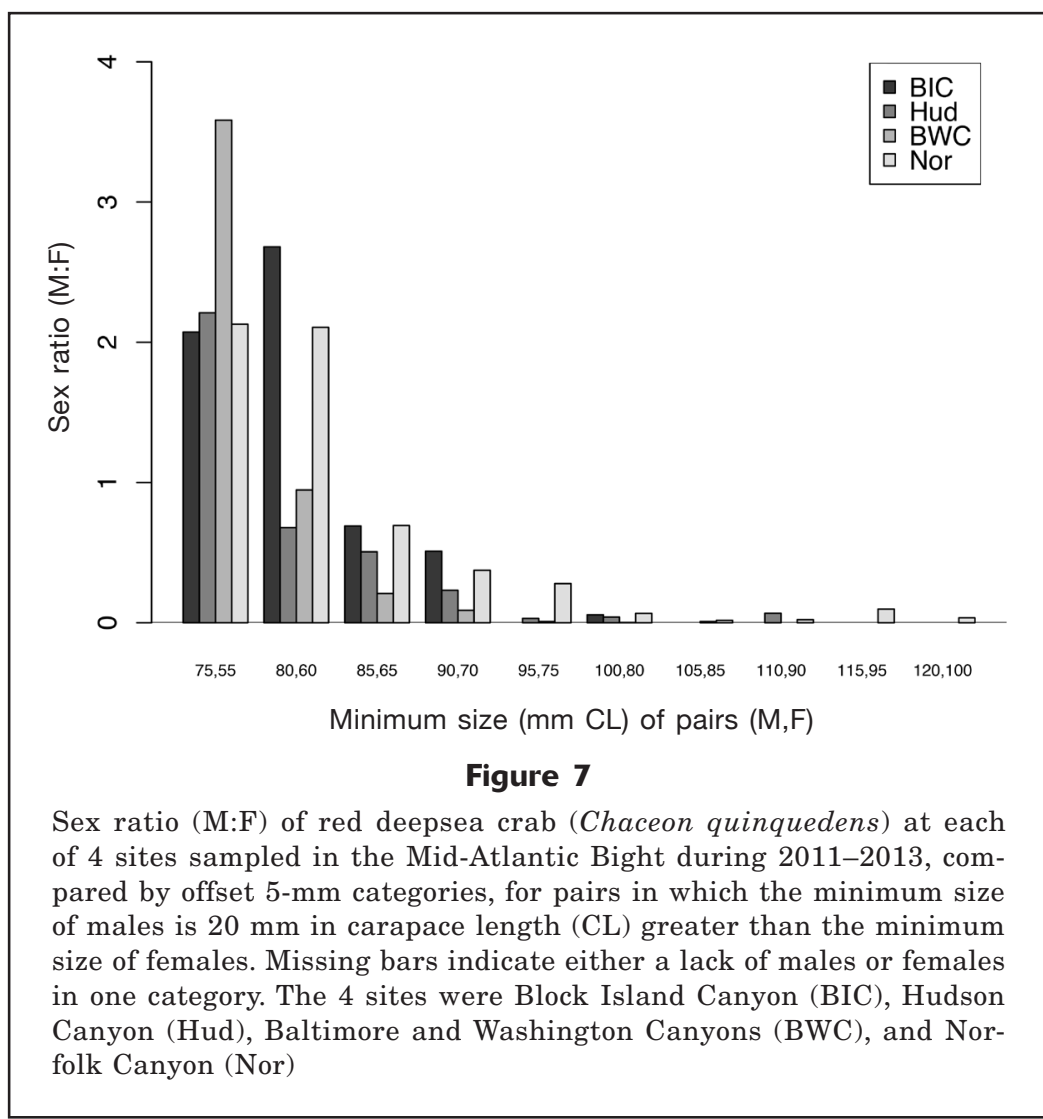




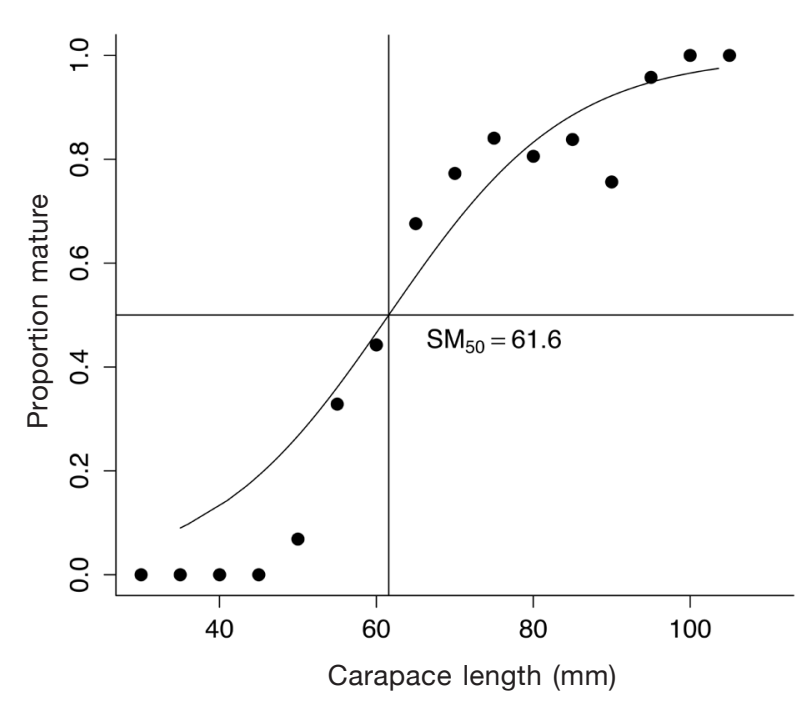

Figure 8

Proportion of female red deepsea crab (Chaceon quinquedens) that were mature (as defined by presence of eggs or condition of the gonopores) in each size group classified in intervals of $5 \mathrm{~mm}$ in carapace length [CL] (circles) and predicted maturity from logistic regression (line). The estimated size at $50 \%$ maturity $\left(\mathrm{SM}_{50}\right)$ was $61.57 \mathrm{~mm} \mathrm{CL}$

Tanner crab (Paul, 1984), and snow crab (Rondeau and Sainte-Marie, 2001). Male southern Tanner crab may mate with as many as 10 partners, but usually with less than 5 (Paul, 1984). Guarding time and the amount of sperm transferred by male snow crabs declines with sex ratio because males try to conserve sperm and, therefore, may leave females with inadequate supplies to fertilize a clutch of eggs (Rondeau and SainteMarie, 2001). Blue crab (Callinectes sapidus) show a marked decline in the rate of courtship initiation at sex ratios below 2 (Jivoff and Hines, 1998). The minimum sex ratio for successful fertilization of all females in a crab population is unknown, but may lie between 0.1 and 0.5 ; a conservative estimate would be 0.25 , indicating that most females above the mean size in our study do not have access to an adequate number of males.

The crab in our study were considerably smaller than C. affinis from the Canary Islands (mean sizes of males and females were 130 and $120 \mathrm{~mm} \mathrm{CW}$ ) (Fernández-Vergaz et al., 2000) or the Azores (107 and 91 mm CL) (Pinho et al., 2001); however, crab in the Canaries and Azores were captured by traps, which are highly size selective; only 3 crab $<80 \mathrm{~mm} \mathrm{CW}$ were caught by Fernández-Vergaz et al. (2000).

\section{Morphometrics}

Sexual maturity in our sample of red deepsea crab cannot be inferred from morphometric characteristics. A variety of methods have been proposed for determining the maturity of crabs. Somerton (1980) described a computer technique that determined $\mathrm{SM}_{50}$ for male crabs by fitting morphometric data with a logistic regression. He defined 4 patterns of allometric growth, based on the relationship between chela and carapace measurements, and applied those relationships to determine size at sexual maturity for male snow crab in the Bering Sea (Somerton, 1981) and later for blue king crab (Paralithodes platypus; Somerton and MacIntosh, 1983). Allometric patterns in species of Chionoecetes are curvilinear, and variation increases with size, but patterns become linear when log-transformed. The slope of the log-transformed relationship is defined as the allometry coefficient.

The relationship between $\mathrm{ChL}$ and $\mathrm{CL}$ for our male red deepsea crab was linear, did not show increased variance with size, and did not require transformation. It has an allometry coefficient of 1.09 , indicating isometric growth and has no inflection point that could be used to define the onset of sexual maturity. The relationship between $\mathrm{ChL}$ and $\mathrm{CL}$ for female crabs, however, indicated clear sexual dimorphism and was negatively allometric. The relationship between male $\mathrm{ChH}$ and $\mathrm{CL}$ was also isometric, with an allometry coefficient of 1.06. Similar to that of males, the relationship between female AW and CL was linear, had no apparent inflexion point corresponding to maturity, and did not differ between maturity types.

Similar results were obtained for $C$. affinis in the Azores; no inflections were found in the relationships between CL and $\mathrm{CW}, \mathrm{ChW}$ (height), or female AW, and 
male:female dimorphism was present in the chelae but not in CW (Pinho et al., 2001). In contrast, allometric relationships for $\mathrm{ChL}$ and $\mathrm{ChW}$ in C. affinis from the Canary Islands were strongly positive (approximately 1.3-1.5) and were used in hierarchical cluster analysis to distinguish immature from mature individuals of both sexes (Fernández-Vergaz et al., 2000). Logistic regression of these crab indicated $\mathrm{SM}_{50}$ values of $129 \mathrm{~mm}$ CW for male C. affinis-a size that would be equivalent to $103 \mathrm{~mm}$ CL for red deepsea crab if converted with the regression of CL on SW for the latter (FernándezVergaz et al., 2000).

Determination of sexual maturity on the basis of morphometrics works well for crabs of the families Oregonidae (Chionoecetes spp.) and Majidae. The spider crab (Maja brachydactyla) shows a typical curvilinear relationship between $\mathrm{CL}$ and $\mathrm{ChH}$ that becomes linear upon log-transformation, and Corgos and Freire (2006) used discriminant analysis to separate immature and mature male clusters. Their data were fitted even better by a 3-stage growth model, which included an inflection point between juveniles and adolescent males. Therefore, excluding one study on C. affinis, morphometric relationships have not proved useful for determining sexual maturity in the genus Chaceon.

\section{Distribution by depth and temperature}

At our sampling sites, highest abundance of red deepsea crab occurred at depths between 500 and $650 \mathrm{~m}$, and few crab were captured at depths $<400 \mathrm{~m}$. Female red deepsea crab dominated catches taken at depths shallower than $600 \mathrm{~m}$, and males were more prevalent at greater depths. Haefner et al. (1974) reported that the highest abundance occurred at depths between 265 and $512 \mathrm{~m}$, and they observed that females dominated trawl catches above $400 \mathrm{~m}$ in and near Norfolk Canyon but that males became dominant below $400 \mathrm{~m}$.

Our data show a slight but significant decline in size of crab with increasing depth-a drop that was much more apparent for females. This decline in size is consistent with other reports that indicate that juvenile red deepsea crab are more common at greater depths (Wahle et al., 2008). We also found that the proportion of males increased with depth. Off the Namibian coast, C. maritae (misidentified as C. quinquedens) show similar depth ranges; females predominate above $400 \mathrm{~m}$ at temperatures of $\sim 8^{\circ} \mathrm{C}$ and males are more abundant down to $900 \mathrm{~m}$ and $4^{\circ} \mathrm{C}$ (Beyers and Wilke, 1980; as cited by Melville-Smith, 1989). In contrast, Kilgour and Shirley (2008) caught red deepsea crab by traps at depths of 533 to $1950 \mathrm{~m}$ in the Gulf of Mexico but found no significant relationships between depth and crab size or sex. Pinho et al. (2001) caught C. affinis with traps around the Azores Islands and found that the highest abundance occurred at depths between 700 and $900 \mathrm{~m}$. In that study, size of both sexes decreased slightly with increasing depth, but the proportion of males declined with increasing depth, in contrast to our results.
Despite differences in depth distribution observed for red deepsea crab in our surveys, the differences in temperature distribution by sex were minor, and much overlap occurred between males and females. Similarly, differences in bottom temperature between years were minor despite sampling in either January or July, and differences weighted by crab catch were even less. These data indicate that temperatures at the depths sampled do not show great annual variation, and red deepsea crab tend to stay within a narrow range of preferred temperature. This information indicates that red deepsea crab recruit as juveniles to waters deeper than those sampled, move upslope during development, and become mature in the shallowest zones, after which they undergo an ontogenetic migration back to intermediate depths.

\section{Female maturity and ovigerity}

Our estimate of $\mathrm{SM}_{50}$ for female red deepsea crab (61.6 $\mathrm{mm} \mathrm{CL}$ ) was calculated by nonlinear logistic regression; therefore, a point estimate was possible. Haefner (1977) estimated female maturity on the basis of the relationship of AW to CL for females classified as mature or immature by gonopore condition, and he determined that maturity occurred over a size range of $65-75 \mathrm{~mm}$ CL. Haefner (1977) calculated 2 separate regression equations for females with mature or immature gonopores (total $n=251$ ) for the relationship between AW and CL that had similar slopes but different intercepts. However, the equation for immature females was influenced by 3 extremely small crab. Likewise, AW of $C$. affinis has been reported to change in intercept at maturity, between 95 and $105 \mathrm{~mm} \mathrm{CW}$ (equivalent to $76-84 \mathrm{~mm}$ CL) (Fernández-Vergaz et al., 2000).

In contrast, covariance analysis of our data did not support the hypothesis that the 2 relationships were different, and there were no extreme outliers (total number of females analyzed=182). Abdomen morphometry indicated that $C$. affinis females become functionally mature (i.e., capable of bearing eggs) before reaching physiological maturity (which is assessed on the basis of apparent ovarian stage) (Fernández-Vergaz et al., 2000). Logistic regression indicated $\mathrm{SM}_{50}$ values of $108 \mathrm{~mm} \mathrm{CW}$ (equivalent to $86.6 \mathrm{~mm} \mathrm{CL}$ ) for abdominal maturity and $113.4 \mathrm{~mm} \mathrm{CW} \mathrm{(91} \mathrm{mm} \mathrm{CL)} \mathrm{for} \mathrm{gonopore}$ maturity of crab in the Canary Islands (FernándezVergaz et al., 2000), whereas the $\mathrm{SM}_{50}$ for female red deepsea crab in the Azores determined by gonopore condition was $83.1 \mathrm{~mm}$ CL (Pinho et al., 2001).

The presence of eggs on $<50 \%$ of female crabs is a strong indicator that reproduction occurs at biennial (or longer) intervals. Haefner (1977) examined female red deepsea crab from the Norfolk Canyon, and reported that only $25.5 \%$ of females $>71 \mathrm{~mm}$ CL were ovigerous in January 1976. He also reported that abraded gonopores were present in $93.5 \%$ of female red deepsea crab $\geq 71 \mathrm{~mm}$ CL but not in any crab $<70 \mathrm{~mm}$ CL. In the Azores, ovigerous C. affinis were found only in the fourth and first quarters of the year, with a maximum 
of $33 \%$ ovigerous crab. Lack of annual mating for red deepsea crab was previously hypothesized by other authors (Weinberg and Keith, 2003). Female C. maritae in South Africa were also reported to have asynchronous molting and aseasonal reproductive cycles (MelvilleSmith, 1989).

Reproductive cycles $>1$ year may occur among crabs living at extremely low temperatures. Blue king crab in the Bering Sea living at temperatures ranging from $-1^{\circ} \mathrm{C}$ to $4^{\circ} \mathrm{C}$ reproduce biennially (Somerton and MacIntosh, 1985; Jensen and Armstrong, 1989; Stevens et al., 2008), and approximately $50 \%$ of females bear fertilized embryos each spring. Female snow crab reproduce biennially in the Gulf of St. Lawrence at temperatures $<1.0^{\circ} \mathrm{C}$ and have only 2 broods over their reproductive lifespan (Moriyasu and Lanteigne, 1998; Comeau et al., 1999), whereas snow crab living at higher temperatures (and greater depths) reproduce annually, potentially producing 4 lifetime broods (Kuhn and Choi, 2011).

Switching from biennial to annual reproduction can potentially halve or double lifetime reproductive output, depending on direction of change (Webb et al., 2007). A change of only $1^{\circ} \mathrm{C}$ can advance or delay hatching of red king crab (Paralithodes camtschaticus) by about 2 weeks, possibly contributing to year class failure from a mismatch between larval hatching and food sources (Stevens et al., 2008). Other crabs with reproductive cycles longer than 1 year include the golden king crab (Lithodes aequispinus) and others that live at depths $>500 \mathrm{~m}$ and produce lecithotrophic larvae (Shirley and Zhou, 1997; Paul and Paul, 2001). Biennial spawning has been reported only for crab species living at temperatures $<4^{\circ} \mathrm{C}$, and for those with lecithotrophic larvae, but has not been reported for crabs with planktotrophic larvae living at temperatures $>6^{\circ} \mathrm{C}$. Therefore, crabs of the genus Chaceon are unusual in this respect.

The extremely low proportion of egg-bearing females and the advance stage of egg development observed in July 2013 indicate that hatching was nearly completed at that time, and some crab bore newly fertilized eggs in very early developmental stages. These observations indicate that hatching and ovulation events are separated by a time interval, possibly up to a year in red deepsea crab (Brachyura). This separation of events is in contrast with the reproductive strategy of red king crab (Anomura), which molt, mate, and extrude a new clutch of eggs within hours after releasing larvae (Stevens and Swiney, 2007). All species of king crab lack the ability to store sperm, however, and, as a result, comparisons to brachyurans are more appropriate. Snow crab (Brachyura) can store sperm, and multiparous crab may use stored sperm to produce additional clutches of eggs; however, those crab that re-mate must do so within 4-7 days after releasing larvae in order to produce viable clutches (Paul and Adams, 1984). Therefore, it appears that red deepsea crab differ from species of Chionoecetes in their ability to separate the process of larval release (and presumably mating) from that of ovulation and fertilization.
The current fishery for red deepsea crab is expanding into the southern portion of the Mid-Atlantic Bight, including the Norfolk and Washington Canyon areas. This expansion is a result of changing abundance, as well as of changes in the availability of processing facilities close to fishing grounds (Williams ${ }^{7}$ ). Therefore, the population targeted by the fishery is different from that fished 20 years or even 10 years previously. The results of this study lay a foundation for other synoptic studies on red deepsea crab in the Mid-Atlantic Bight. As we went to press (May 2016), we were continuing our work with red deepsea crab, analyzing tissue samples from crab collected during the cruises in 2011-2013, as well as from samples collected aboard commercial fishing vessels in 2014 and 2015. The results of this further analysis should reveal more details about the biology of the red deepsea crab, including size at maturity, reproductive cycles, fecundity, and embryonic and larval development.

\section{Acknowledgments}

This research was conducted with partial funding from the NOAA Living Marine Resources Cooperative Science Center, NOAA grant NA11SEC4810002. We gratefully acknowledge the assistance of the officers and crews of the NOAA Ships Delaware II and Gordon Gunter. We also appreciate the efforts of student participants on all 3 cruises, who were too numerous to name individually; still, major assistance to this project was provided by B.-J. Peemoeller, A. Stoneman, and I. Suyuheda. We thank R. Langton for his service as cochief scientist in 2013 and to S. Smith and S. Van Sant for their participation as watch supervisors during the 2012 and 2013 cruises, respectively. Comments from L. Stehlik and anonymous reviewers helped improve the manuscript.

\section{Literature cited}

Beyers, C. J. D. B., and C. G. Wilke.

1980. Quantitative stock survey and some biological and morphometric characteristics of the deep-sea red crab Geryon quinquedens off South West Africa. Fish. Bull. (S. Afr.) 13:9-19.

Comeau, M., and G. Y. Conan.

1992. Morphometcry and gonad maturity of male snow crab, Chionecetes opilio. Can. J. Fish. Aquat. Sci. 49:2460-2468. Article

Comeau, M., M. Starr, G. Y. Conan, G. Robichaud, and J.-C. Therriault.

1999. Fecundity and duration of egg incubation for multiparous female snow crabs (Chionoecetes opilio) in the fjord of Bonne Bay, Newfoundland. Can. J. Fish. Aquat. Sci. 56:1088-1095. Article

Corgos, A., and J. Freire.

2006. Morphometric and gonad maturity in the spider

${ }^{7}$ Williams, J. 2014. Personal commun. The Atlantic Red Crab Co., New Bedford, MA 02740. 
crab Maja brachydactyla: a comparison of methods for estimating size at maturity in species with determinate growth. ICES J. Mar. Sci. 63:851-859. Article

Elner, R. W., S. Koshio, and G. V. Hurley.

1987. Mating behavior of the deep-sea red crab, Geryon quinquedens Smith (Decapoda, Brachyura, Geryonidae). Crustaceana 52:194-201.

Fernández-Vergaz, V., L. J. López Abellán, and E. Balguerías. 2000. Morphometric, functional and sexual maturity of the deep-sea red crab Chaceon affinis inhabiting Canary Island waters: chronology of maturation. Mar. Ecol. Prog. Ser. 204:169-178. Article

Haefner, P. A., Jr.

1977. Reproductive biology of the female deep-sea red crab, Geryon quinquedens, from the Chesapeake Bight. Fish. Bull. 75:91-102.

1978. Seasonal aspects of the biology, distribution and relative abundance of the deep-sea red crab Geryon quinquedens Smith, in the vicinity of the Norfolk Canyon, western North Atlantic. Proc. Natl. Shellfish. Assoc. 68:49-62.

Haefner, P. A., and J. A. Musick.

1974. Observations on distribution and abundance of red crabs in Norfolk Canyon and adjacent continental slope. Mar. Fish. Rev. 36(1):31-34.

Hastie, L. C.

1995. Deep-water geryonid crabs: a continental slope resource. In Oceanography and marine biology: an annual review, vol. 33 (H. Barnes, A. D. Ansell, and R. N. Gibson), p. 561-584. Univ. College London Press, London.

Hines, A. H.

1988. Fecundity and reproductive output in two species of deep-sea crabs, Geryon fenneri and G. quinquedens (Decapoda: Brachyura). J. Crustac. Biol. 8:557-562. Article

Hinsch, G. W.

1988a. Morphology of the reproductive tract and seasonality of reproduction in the golden crab Geryon fenneri from the eastern Gulf of Mexico. J. Crustac. Biol. 8:254-261. Article

$1988 \mathrm{~b}$. Ultrastructure of the sperm and spermatophores of the golden crab Geryon fenneri and a closely related species, the red crab G. quinquedens, from the eastern Gulf of Mexico. J. Crustac. Biol. 8:340-345. Article

Jadamec, L. S., W. E. Donaldson, and P. Cullenberg.

1999. Biological field techniques for Chionoecetes crabs. Alaska Sea Grant College Program, AK-SG-99-02, 80 p. [Available at website.]

Jensen, G. C., and D. A. Armstrong.

1989. Biennial reproductive cycle of blue king crab, Paralithodes platypus, at the Pribilof Islands, Alaska and comparison to a congener, P. camtschaticus. Can. J. Fish. Aquat. Sci. 46:932-940. Article

Jivoff, P., and A. H. Hines.

1998. Effect of female molt stage and sex ratio on courtship behavior of the blue crab Callinectes sapidus. Mar. Biol. 131:533-542. Article

Kilgour, M. J., and T. C. Shirley.

2008. Distribution of red deepsea crab (Chaceon quinquedens) by size and sex in the Gulf of Mexico. Fish. Bull. 106:317-320.

Kuhn, P. S., and J. S. Choi.

2011. Influence of temperature on embryo developmental cycles and mortality of female Chionoecetes opilio (snow crab) on the Scotian Shelf, Canada. Fish. Res. 107:245-252. Article
López Abellán, L. J., E. Balguerías, and V. Fernández-Vergaz. 2002. Life history characteristics of the deep-sea crab Chaceon affinis population off Tenerife (Canary Islands). Fish. Res. 58:231-239. Article

McRae, E. D.

1961. Red crab explorations off the northeastern coast of the United States. Commer. Fish. Rev. 23:5-10.

Melville-Smith, R.

1989. A growth model for the deep-sea red crab (Geryon maritae) off South West Africa/Namibia (Decapoda, Brachyura). Crustaceana 56:279-292.

Moriyasu, M., and C. Lanteigne.

1998. Embryo development and reproductive cycle in the snow crab, Chionoecetes opilio (Crustacea: Majidae), in the southern Gulf of St. Lawrence, Canada. Can. J. Zool. 76:2040-2048. Article

Nevissi, A., J. M. Orensanz, A. J. Paul, and D. A. Armstrong. 1996. Radiometric estimation of shell age in Chionoecetes spp. from the eastern Bering Sea, and its use to interpret shell condition indices: preliminary results. In High latitude crabs: biology, management, and economics. Alaska Sea Grant College Program Rep. AK-SG-96-02 (B. Baxter, ed.), p. 389-396. [Available at website.]

Paul, A. J.

1984. Mating frequency and viability of stored sperm in the Tanner crab Chionoecetes bairdi (Decapoda, Majidae). J. Crustac. Biol. 4:375-381.

Paul, A. J., and A. E. Adams.

1984. Breeding and fertile period for female Chionoecetes bairdi (Decapoda, Majidae). J. Crustac. Biol 4:589-594. Article

Paul, A. J., and J. M. Paul.

2001. The reproductive cycle of golden king crab Lithodes aequispinus (Anomura: Lithodidae). J. Shellfish Res. 20:369-371

Pinho, M. R., J. M. Gonçalves, H. R. Martins, and G. M. Menezes.

2001. Some aspects of the biology of the deep-water crab, Chaceon affinis (Milne-Edwards and Bouvier, 1894) off the Azores. Fish. Res. 51:283-295. Article

$\mathrm{R}$ Core Team.

2013. R: a language and environment for statistical computing. R Foundation for Statistical Computing, Vienna, Austria. [Available from website, accessed 15 April 2016.]

Robinson, M

2008. Minimum landing size for Northeast Atlantic stocks of deep-water red crab, Chaceon affinis (Milne Edwards and Bouvier, 1894). ICES J. Mar. Sci. 65:148-154. Article

Rondeau, A., and B. Sainte-Marie.

2001. Variable mate-guarding time and sperm allocation by male snow crabs (Chionoecetes opilio) in response to sexual competition, and their impact on the mating success of females. Biol. Bull. 201:204-217.

Sainte-Marie, B., N. Urbani, J.-M. Sévigny, F. Hazel, and U. Kuhnlein.

1999. Multiple choice criteria and the dynamics of assortative mating during the first breeding season of female snow crab, Chionoecetes opilio (Brachyura, Majidae). Mar. Ecol. Prog. Ser. 181:141-153. Article

Shirley, T. C., and S. Zhou.

1997. Lecithotrophic development of the golden king crab Lithodes aequispinus (Anomura: Lithodidae). J. Crustac. Biol. 17:207-216. Article 
Somerton, D. A.

1980. A computer technique for estimating the size of sexual maturity in crabs. Can. J. Fish. Aquat. Sci. 37:1488-1494. Article

1981. Regional variation in the size and maturity of two species of Tanner crab (Chionoecetes bairdi and $C$. opilio) in the eastern Bering Sea, and its use in defining management subareas. Can. J. Fish. Aquat. Sci. 38:163-174. Article

Somerton, D. A., and R. A. MacIntosh.

1983. The size at sexual maturity of blue king crab, Paralithodes platypus, in Alaska. Fish. Bull. 81:621-625.

1985. Reproductive biology of the female blue king crab Paralithodes platypus near the Pribilof Islands, Alaska. J. Crustac. Biol. 5:365-376.

Steimle, F. W., C. A. Zetlin, and S. Chang.

2001. Essential Fish Habitat Source Document: red deepsea crab, Chaceon (Geryon) quinquedens, life history and habitat characteristics. NOAA Tech. Memo. NMFSNE-163, $27 \mathrm{p}$

Stevens, B. G., and K. M. Swiney.

2007. Hatch timing, incubation period, and reproductive cycle for captive primiparous and multiparous red king crab Paralithodes camtschaticus. J. Crustac. Biol. 27:37-48. Article

Stevens, B. G., K. M. Swiney, and L. Buck.

2008. Thermal effects on embryonic development and hatching for blue king crab Paralithodes platypus (Brandt, 1850) held in the laboratory, and a method for predicting dates of hatching. J. Shellfish Res. 27:1255-1263. Article
Stevens, B. G., W. E. Donaldson, J. A. Haaga, and J. E. Munk. 1993. Morphometry and maturity of male Tanner crabs, Chionoecetes bairdi, from shallow- and deepwater environments. Can. J. Fish. Aquat. Sci. 50:1504-1516. Article

Tallack, S. M. L.

2007. Escape ring selectivity, bycatch, and discard survivability in the New England fishery for deep-water red crab, Chaceon quinquedens. ICES J. Mar. Sci. 64:1579-1586. Article

Wahle, R. A., C. E. Bergeron, A. S. Chute, L. D. Jacobson, and Y. Chen.

2008. The Northwest Atlantic deep-sea red crab (Chaceon quinquedens) population before and after the onset of harvesting. ICES J. Mar. Sci. 65:862-872. Article

Webb, J. B., G. L. Eckert, T. C. Shirley, and S. L. Tamone. 2007. Changes in embryonic development and hatching in Chionoecetes opilio (snow crab) with variation in incubation temperature. Biol. Bull. 213:67-75.

Weinberg, J. R., and C. Keith.

2003. Population size-structure of harvested deep-sea red crabs (Chaceon quinquedens) in the northwest Atlantic Ocean. Crustaceana 76:819-833.

Wenner, E. L., and C. A. Barans.

1990. In situ estimates of density of golden crab, Chaceon fenneri, from habitats on the continental slop, southeastern U.S. Bull. Mar. Sci. 46:723-734.

Wigley, R. L., R. B. Theroux, and H. E. Murray.

1975. Deep sea red crab, Geryon quinquedens, survey off northeastern United States. Mar. Fish. Rev. 37(8):1-21. 